\title{
Bioactive Compounds in Waste By-Products from Olive Oil Production: Applications and Structural Characterization by Mass Spectrometry Techniques
}

\author{
Ramona Abbattista ${ }^{1}$, Giovanni Ventura ${ }^{1}\left(\mathbb{D}\right.$, Cosima Damiana Calvano ${ }^{2,3, *(\mathbb{D})}$, Tommaso R. I. Cataldi ${ }^{1,2} \mathbb{D}$ \\ and Ilario Losito $1,2, *$ (i) \\ 1 Chemistry Department, University of Bari Aldo Moro, via Orabona 4, 70126 Bari, Italy; \\ ramona.abbattista@uniba.it (R.A.); giovanni.ventura@uniba.it (G.V.); tommaso.cataldi@uniba.it (T.R.I.C.) \\ 2 Interdepartmental Centre SMART, University of Bari Aldo Moro, via Orabona 4, 70126 Bari, Italy \\ Pharmacy-Pharmaceutical Sciences, University of Bari Aldo Moro, via Orabona 4, 70126 Bari, Italy \\ * Correspondence: cosimadamiana.calvano@uniba.it (C.D.C.); ilario.losito@uniba.it (I.L.)
}

check for updates

Citation: Abbattista, R.; Ventura, G.; Calvano, C.D.; Cataldi, T.R.I.; Losito, I. Bioactive Compounds in Waste By-Products from Olive Oil Production: Applications and Structural Characterization by Mass Spectrometry Techniques. Foods 2021, 10, 1236. https://doi.org/10.3390/ foods10061236

Academic Editor: Enrico Valli

Received: 30 April 2021

Accepted: 27 May 2021

Published: 29 May 2021

Publisher's Note: MDPI stays neutra with regard to jurisdictional claims in published maps and institutional affiliations.

Copyright: (C) 2021 by the authors Licensee MDPI, Basel, Switzerland. This article is an open access article distributed under the terms and conditions of the Creative Commons Attribution (CC BY) license (https:// creativecommons.org/licenses/by/ $4.0 /)$

\begin{abstract}
In recent years, a remarkable increase in olive oil consumption has occurred worldwide, favoured by its organoleptic properties and the growing awareness of its health benefits. Currently, olive oil production represents an important economic income for Mediterranean countries, where roughly $98 \%$ of the world production is located. Both the cultivation of olive trees and the production of industrial and table olive oil generate huge amounts of solid wastes and dark liquid effluents, including olive leaves and pomace and olive oil mill wastewaters. Besides representing an economic problem for producers, these by-products also pose serious environmental concerns, thus their partial reuse, like that of all agronomical production residues, represents a goal to pursue. This aspect is particularly important since the cited by-products are rich in bioactive compounds, which, once extracted, may represent ingredients with remarkable added value for food, cosmetic and nutraceutical industries. Indeed, they contain considerable amounts of valuable organic acids, carbohydrates, proteins, fibers, and above all, phenolic compounds, that are variably distributed among the different wastes, depending on the employed production process of olive oils and table olives and agronomical practices. Yet, extraction and recovery of bioactive components from selected by-products constitute a critical issue for their rational valorization and detailed identification and quantification are mandatory. The most used analytical methods adopted to identify and quantify bioactive compounds in olive oil by-products are based on the coupling between gas- (GC) or liquid chromatography (LC) and mass spectrometry (MS), with MS being the most useful and successful detection tool for providing structural information. Without derivatization, LC-MS with electrospray (ESI) or atmospheric pressure chemical (APCI) ionization sources has become one of the most relevant and versatile instrumental platforms for identifying phenolic bioactive compounds. In this review, the major LC-MS accomplishments reported in the literature over the last two decades to investigate olive oil processing by-products, specifically olive leaves and pomace and olive oil mill wastewaters, are described, focusing on phenolics and related compounds.
\end{abstract}

Keywords: LC-ESI-MS; MALDI-MS; bioactive phenolics; olive oil; olive leaves; olive pomace; olive oil mill wastewater

\section{Introduction}

The production of high-quality olive oils implies the generation of vast quantities of solid residues and/or wastewaters that may have a great impact on terrestrial and aquatic environments because of their high phytotoxicity [1]. Depending on the techniques used for olive oil production, namely, on the type of horizontal centrifugation (two-phase or three-phase), the process most adopted to separate olive oil from olive paste obtained after malaxation, different by-products are obtained (Figure 1). 


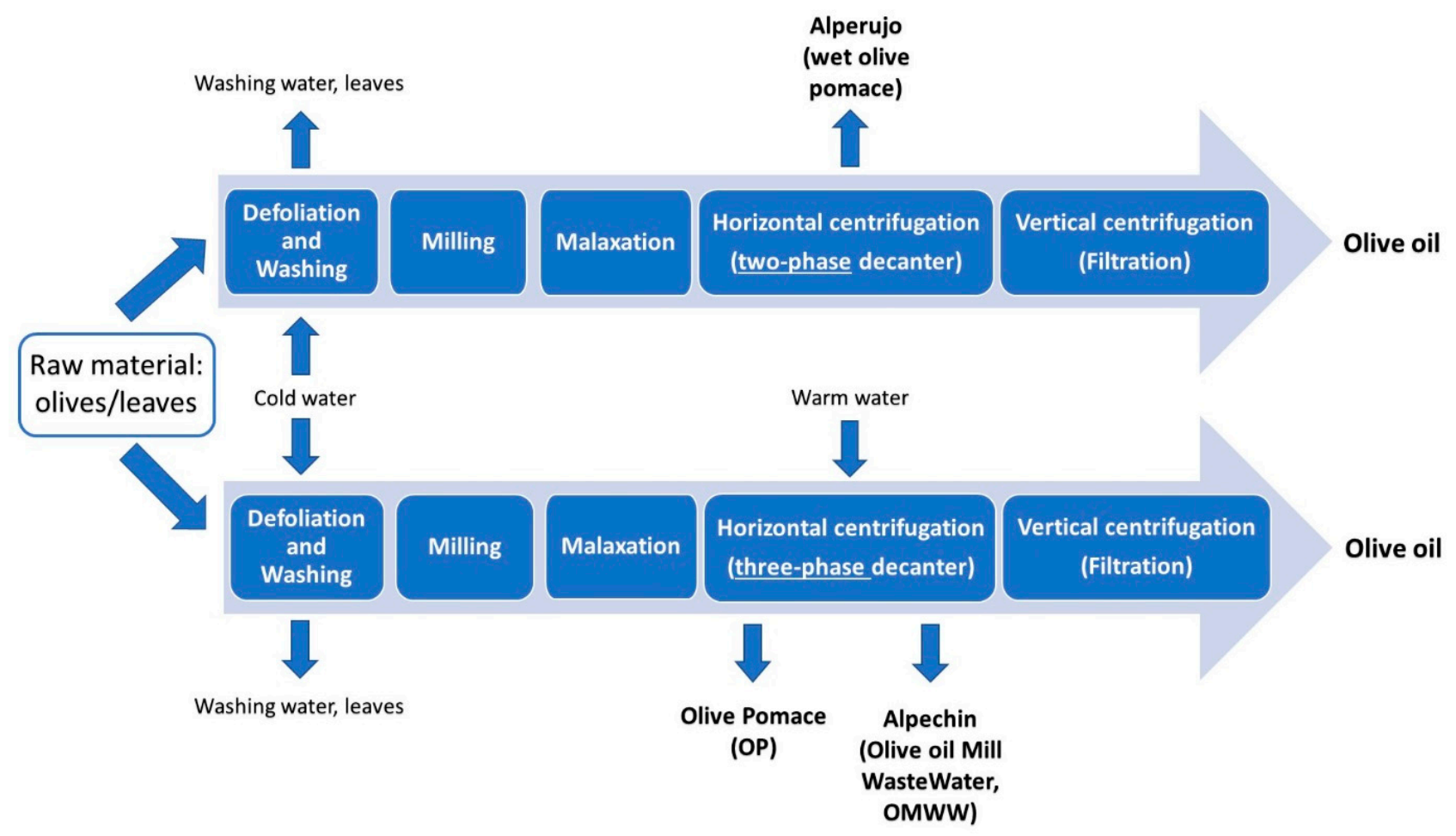

Figure 1. Layout of the main steps of olive oil production involving two- or three-phase horizontal centrifugation and the main by-products obtained.

When two-phase decanters are used for horizontal centrifugation, whereby water is not purposely added to the olive paste resulting from malaxation, a humid semi-solid pomace is obtained as by-product (wet olive pomace, wet $\mathrm{OP}$, or alperujo), consisting in olive pulp and husk, crushed olive stone and aqueous solution. In the case of threephase centrifugal technology, solid OP and olive oil mill wastewater (OMWW) or alpechin are the two major by-products. Notably, the modern two-phase centrifugal extraction technology merges OP with OMWW to produce a single by-product named olive mill waste (OMW) [2]. OMW shows a broad spectrum of toxicity, antimicrobial activity, high acidity and phytotoxicity, that make its biological degradation challenging and its disposal problematic for major producing countries (all located in the Mediterranean basin), given the significant amounts of OMW generated every year. Research efforts have thus been focused on valorizing the OMW in various ways, such as using it as energy source [3] or as fertilizer, biomass, or additive in animal feed [4]. However, a large quantity of byproducts resulting from olive oil production remains unexploited, with their potentially high biological value being neglected. Indeed, wastes remaining after the production of olive oil are a heterogeneous mixture of many chemical components, such as metal ions, carbohydrates, and polyphenols, that may exert different biological activities, primarily acting as antioxidants [5]. Phenolic compounds from olive fruits are mostly retained in the corresponding waste, whereas just a small percentage (ca. $2 \%$ ) is transferred to olive oils during production, thus making by-products an interesting alternative source of natural antioxidants for application in the food and pharmaceutical industries $[5,6]$. In the last few years, health benefits related to the assumption of novel olive by-products-based preparations have encouraged the research to identify the main compounds recognized for their positive physiological effects. In this context, the phenolic composition of olive oil production by-products has been extensively studied and several authors have applied chromatographic methods for their isolation and analysis, such as reversed-phase liquid chromatography (RPLC) coupled to mass spectrometry (MS) [7,8], fractionation by solidphase extraction (SPE) and LC retention-time identification $[9,10]$, preparative HPLC and capillary zone electrophoresis (CZE) with UV diode array detection (DAD) [11]. As 
emphasized by researches dealing with one of the most important classes of bioactive compounds related to olive oil, i.e., secoiridoids (see, for example, ref. [12]), MS provides the analytical strength for a highly detailed structural characterization, including the distinction of isomeric compounds.

After a survey on the general features and the main applications reported so far for olive oil by-products, including olive leaves, pomace, and olive mill wastewater, with a special emphasis on the correlation between their content of high-added value compounds and their reuse, this review will focus on the literature concerning the use of MS techniques for the extended characterization of the most relevant bioactive compounds in these matrices. Quantitative data, where available, obtained on specific compounds will be also reported and discussed in the perspective of individuating which compounds (or class of compounds) may deserve the development of appropriate recovery strategies from olive oil production by-products.

\section{High-Added Value Compounds in Olive Oil Production Wastes}

\subsection{Olive Leaves}

Olive leaves represent an agricultural waste by-product obtained during the harvesting of olive trees for table olives and olive oil production chains $[13,14]$. It has been estimated that pruning alone produces annually $25 \mathrm{~kg}$ of waste represented by branches and leaves per olive tree [15]. A considerable amount of olive leaves is also discarded during the olive drupes washing process at the beginning of the olive oil production chain (see Figure 1), reaching a value ranging from $8 \%$ [16] to $10 \%$ [17] of the total weight of olives subjected to milling. In general, olive leaves are not included in the definition of olive mill solid waste [18] but, together with olive stones, they are described as solid residue [19]. The use of solid residue is of great economic and social importance for the Mediterranean area, as it is accumulated in large amounts [19]. Although limited by their pungency, olive leaves are traditionally used in many countries as feed for livestock or simply disposed by burning. Olive leaves represent a potential source of bioactive compounds, as indirectly proved by the use of their extracts in the context of folk medicine for centuries, with the first medicinal application attested in history dating back to the ancient Egyptian civilization [13]. During centuries, the use of olive leaves preparations in traditional medicine has spread in many different countries [20] (see Table 1). Recently, preparations based on olive leaves, in the form of liquid extracts or tablets, have been commercialised as natural supplements against diabetes, high blood pressure, cardiovascular diseases, urinary tract infections, chronic fatigue symptoms and to improve immune system [21]. Olive leaves preparations also find their application in the cosmetic industry for their anti-ageing activity, and due to their antibiotic and antiparasitic properties as supplements for animal health [22]. Moreover, olive leaves extracts may be used as additives to increase food shelf-life, safety and functionality for their antioxidant and antimicrobial features $[23,24]$. Interestingly, their probiotic properties have been recently found to promote the Lactobacillus casei survival during cold storage of cheese [25]. Their addition to beer [26] and to a Southern Italy traditional cereal-based baked product known as taralli [17] has been found to increase the inherent polyphenols content of these products. It is also worth noting that phenolic compounds and tocopherols, normally found in olive oils, play a protective role against oxidative stress [27] and are able to extend the extra virgin olive oil shelf-life due to their antioxidant properties [28]. Since the use of synthetic antioxidants may lead to health risks, recent papers have featured that olive leaves, having a high antioxidant activity [29-31] due to their phenolics, can exhibit strong preventive effects against olive oil oxidation. The addition of olive leaves during oil extraction process, specifically during olive milling, has thus been recently evaluated in detail and found to lead to the enrichment in chlorophyll [32,33], carotenoids, flavonoids, and in the derivatives of oleuropein, which is the main secoiridoid occurring in olive leaves (see Figure 2) [34]. 
Table 1. Main uses of olive leaves in traditional medicine occurring worldwide.

\begin{tabular}{|c|c|c|c|c|}
\hline Country & $\begin{array}{l}\text { Assumption Form of Olive } \\
\text { Leaf-Based Products }\end{array}$ & Route & Treatments & References \\
\hline Arabic countries & Dried plant fumigation & Nasal & $\begin{array}{c}\text { Abortifacient, and treatment of } \\
\text { cystitis and sore throat }\end{array}$ & [35] \\
\hline Brazil & Herbal tea of the fresh leaves & Oral & $\begin{array}{l}\text { To induce diuresis, and } \\
\text { treatment of hypertension }\end{array}$ & [36] \\
\hline Canary Islands & $\begin{array}{l}\text { An infusion prepared from the } \\
\text { fresh or dried leaves }\end{array}$ & Oral/rectal & $\begin{array}{l}\text { Treatment of diabetes; hypertension } \\
\text { and haemorrhoids }\end{array}$ & {$[37]$} \\
\hline France & $\begin{array}{l}\text { Powdered dried leaves } \\
\text { as hard capsules }\end{array}$ & Oral & $\begin{array}{l}\text { To promote urinary and digestive } \\
\text { elimination functions }\end{array}$ & {$[38]$} \\
\hline Germany & $\begin{array}{l}\text { Extract with ethanol } 96 \% v / v \\
\text { as liquid or coated tablet }\end{array}$ & Oral & $\begin{array}{l}\text { Treatment of atherosclerosis } \\
\text { and hypertension }\end{array}$ & {$[38]$} \\
\hline Italy & $\begin{array}{l}\text { Infusion of the dried leaf } \\
\text { Infusion of the fresh leaf }\end{array}$ & Oral & $\begin{array}{l}\text { Treatment of hypertension and } \\
\text { anti-inflammatory; for wound } \\
\text { healing, emollient for ingrown nails } \\
\text { and to restore epithelium }\end{array}$ & {$[39,40]$} \\
\hline Morocco & $\begin{array}{l}\text { Leaves and essential oil } \\
\text { from the leaves }\end{array}$ & $\begin{array}{c}\text { Oral } \\
\text { Topical }\end{array}$ & $\begin{array}{l}\text { Treatment of stomach and intestinal } \\
\text { disease and as a mouth cleanser; } \\
\text { treatment of constipation and liver } \\
\text { pain; tonic for hairs }\end{array}$ & [41] \\
\hline Trinidad & Hot water extract of the leaf & Oral & $\begin{array}{l}\text { To increase milk supply } \\
\text { of nursing mother }\end{array}$ & [42] \\
\hline Ukraine & $\begin{array}{l}\text { Hot water extract of } \\
\text { dried plant }\end{array}$ & Oral & Treatment of bronchial asthma & [43] \\
\hline
\end{tabular}

The promising antimicrobial and antioxidant hallmarks of phenols contained in olive leaves by-products have also led to produce bio-active films for food packaging by integrating olive leaf extract or powder in plastic polymers [44,45].

\subsection{Olive Pomace and Olive Oil Mill Wastewater}

According to Decision 2000/532/EC of the European Union Commission and to the Eurostat database classification [46], waste from agricultural activities (i.e., corn, wheat, fruit, vegetables, rice, pomace, olive wastes) are included in the agricultural livestock waste (ALW) category. Just to give an idea of the amount of ALW in 2016 resulting from olive oil production, 22 and 14 thousands of tons of olive pomace were generated, respectively, in Apulia and Sicily, two of the major olive oil producers in Italy [47]. Such amounts are not surprising, since approximately $800 \mathrm{~kg}$ of pomace and $200 \mathrm{~kg}$ of wastewater are on average obtained for $200 \mathrm{~kg}$ of extra virgin olive oils. To avoid endangering human health and to protect the environment, a rational waste management including prevention, reuse, recycling, recovery, and disposal is crucial also for such by-products [48].

As previously mentioned, the type of horizontal centrifugation adopted during olive oil production can determine the main features of OP, which is humid and semisolid, with a moisture content between 50 and $70 \%$, when two-phase decanters are used, whereas moisture is decreased if three-phase decanters (35-40\%) or traditional press mills $(20-25 \%)$ are employed [49]. The average rough composition of OP has been reported as follows: water $(60-70 \%)$, lignin (13-15\%), cellulose and hemicellulose (18-20\%), olive oil retained in the pulp (2.5-3\%) and mineral solids (2.5\%) [2]. Major organic compounds are sugars $(3 \%)$, volatile fatty acids $(\mathrm{C} 2-\mathrm{C} 7)(1 \%)$, poly-alcohols $(0.2 \%)$, proteins $(1.5 \%)$, polyphenols $(0.2 \%)$ and pigments $(0.5 \%)$ [2]. The profile vitamin E occurring in OP includes $\alpha$-tocopherol, $\beta$-tocopherol, $\alpha$-tocotrienol and $\gamma$-tocopherol, being $\alpha$-tocopherol the major form $(>2.6 \mathrm{mg} / 100 \mathrm{~g})$. The lipid fraction is particularly rich in oleic acid (ca. $75 \%)$, followed 
by palmitic, linoleic, and stearic acids; hydroxytyrosol and comselogoside represent around the $80 \%$ of the total phenolics in OP [50].

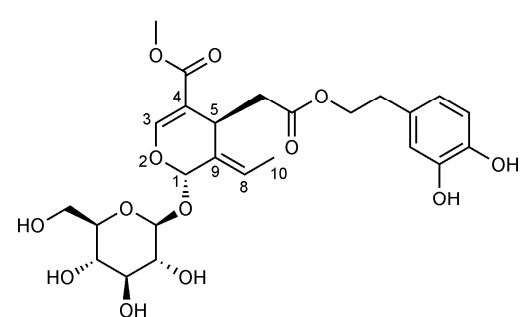

Oleuropein

$\mathrm{C}_{25} \mathrm{H}_{32} \mathrm{O}_{13}$<smiles>COC(=O)C1=CO[C@H](O)C2=COC(=O)CC12CC(=O)O</smiles><smiles>C/C=C(\C=O)C(CC=O)CC(=O)OCCc1ccc(O)c(O)c1</smiles>
$\mathrm{C}_{17} \mathrm{H}_{20} \mathrm{O}_{6}$

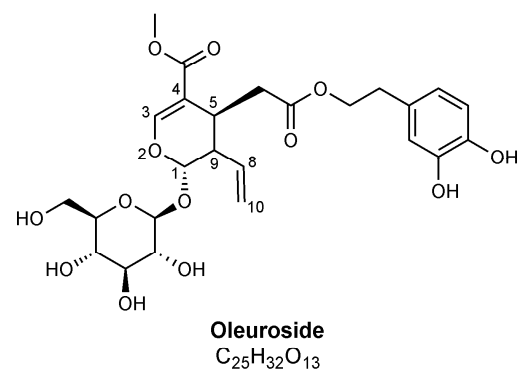<smiles>COC(=O)C1=CO[C@@H](O[C@@H]2O[C@H](CO)[C@@H](O)[C@H](O)[C@H]2O)C2=COC(OC[C@H]3O[C@@H](OCCc4ccc(O)cc4)[C@@H](O)[C@H](O)[C@H]3O)CC12</smiles>

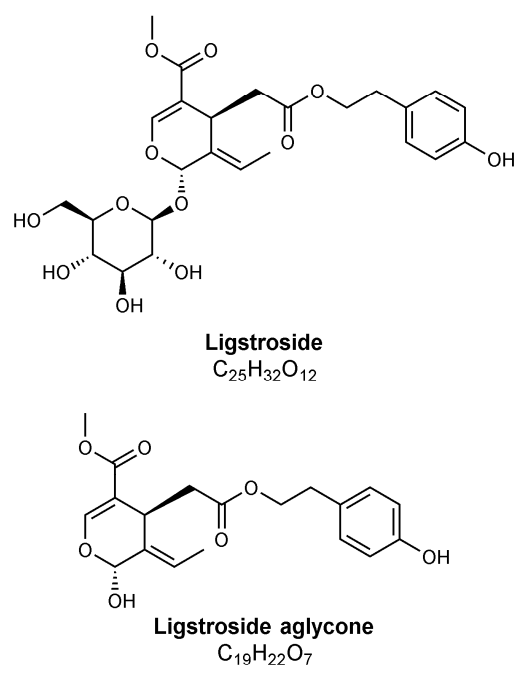<smiles>CC=C(C=O)C(CC=O)CC(=O)OCCc1ccc(O)cc1</smiles>

Oleocanthal

$\mathrm{C}_{17} \mathrm{H}_{20} \mathrm{O}_{5}$<smiles>C/C=C1\C(CC(=O)O)C(C(=O)O)=CO[C@H]1O[C@H]1O[C@H](CO)[C@@H](O)[C@H](O)[C@H]1O</smiles><smiles>C=C[C@H]1[C@@H](O[C@@H]2OC(COC(=O)/C=C/c3ccc(O)c(O)c3)[C@@H](O)[C@H](O)[C@H]2O)OC=C(C(=O)O)[C@@H]1CC(=O)O</smiles><smiles>C/C=C1\C(CC(=O)O)C(C(=O)OC)=CO[C@H]1O[C@@H]1O[C@H](CO)[C@@H](O)[C@H](O)[C@H]1O</smiles>

Elenolic acid glucoside $\mathrm{C}_{17} \mathrm{H}_{24} \mathrm{O}_{11}$<smiles>C/C=C1\C(C(=O)O)C(C(=O)OC)=CO[C@H]1C</smiles><smiles>CC=C(C=O)C(CC=O)CC(=O)O</smiles>

Decarboxymethyl-Elenolic acid

$\mathrm{C}_{9} \mathrm{H}_{12} \mathrm{O}_{4}$<smiles>C=CC1C(O[C@@H]2OC(CO)[C@@H](O)[C@H](O)[C@H]2O)OC=C(C(=O)O)C1CC(=O)O</smiles><smiles>C=C[C@H]1[C@H](O[C@@H]2OC(COC(=O)/C=C/c3ccc(O)cc3)[C@@H](O)[C@H](O)[C@H]2O)OC=C(C(=O)O)[C@@H]1CC(=O)O</smiles>

Figure 2. Chemical structures of major secoiridoids identified in olive leaves, pomace and in olive oil mill wastewater using MS techniques. Note that hemiacetalic forms of elenolic acid and of oleuropein and ligstroside aglycones are reported; dialdehydic open-structure isoforms are indicated for oleac(e)in, oleocanthal and decarboxymethyl-elenolic acid. The carbon atoms numbering typically adopted for secoiridoids has been reported for oleuropein and oleuroside to emphasize the positional isomerism occurring for these compounds, related to the position of the exocyclic $\mathrm{C}=\mathrm{C}$ bond.

Since OP consists essentially of olive pulp, olive stone and vegetation water, it includes many of the valuable components of the olive fruit so it can be subjected to biorefining, i.e., to the extraction of valuable compounds and energy. OP is mostly used for the recovery of pomace oil by solid-liquid extraction with hexane, followed by distillation and solvent 
recycling. The crude oil is then refined and typically blended with a small amount of virgin olive oil. Furthermore, after OP is evaporated and thermally concentrated, it can be applied to cultivated soils as herbicide, insecticide, and compost. Indeed, due to the polysaccharide occurrence, dried OP represents a potential source of gelling pectic material. As an example, Lama-Munoz et al. isolated sugars from alperujo by ethanol/water precipitation, obtaining various oligosaccharide fractions as pectin, neutral and acidic xylo-oligosaccharides, and xyloglucan oligosaccharides with diverse applications as gelling agents, stabilizers and emulsifiers for the food industry [51]. Alperujo compost at different doses was evaluated by Tortosa et al. [52] as an organic manure, mixed with a minimal amount of inorganic fertilizers, for pepper growth in greenhouse cultivations. The authors speculated that the organic matter from alperujo compost positively affects pepper oxidative metabolism by increasing the antioxidative enzymatic activities. Hence, the yield and physiological growth of plants would be improved or rather comparable to standard nutrient solutions. OP is also considered a source of bioethanol, biogas, and methane [53]; residuals of olive stones in OP can be the substrate to obtain activated carbon that can be employed as fuel for the generation of heat and electricity [19]. Moreover, alperujo oil has been used as a non-edible substrate with a high-free fatty acid content for the synthesis of biodiesel through an enzymatic path based on recombinant 1,3-positional specific Rhizopus oryzae lipase, avoiding the generation of glycerol as a co-product [54]. Another fascinating alternative of OP valorization is its use as a substrate for growing microorganisms of biotechnological interest [55]. This strategy offers the opportunity of producing high value-added products, such as enzymes, biopolymers, and pigments with a concomitant reduction of organic wastes. Ghilardi et al. explored the possibility to produce carotenoids by a strain of Rhodotorula mucilaginosa using different media derived from alperujo as a cheap substrate [55]. According to the medium used, it was possible to obtain a mixture of carotenoids enriched in torulene, torularhodin and/or neurosporene, thus showing that alperujo can be used to produce carotenoids exploitable at industrial scale, as additives in pharmaceutical, food and feed products [55].

OP has been applied even in the construction field. De la Casa et al. [56] reported the addition of alperujo to the ceramic paste of bricks, lowering density and thermal conductivity. The OP residue was also used as a substitute for clay in 1.25, 2.5 and $5 \%$ (wt) of artificial lightweight aggregate manufactures [57]. The results indicated that the addition of $\mathrm{OP}$ in the mixture is beneficial in terms of environmental impact compared to that related to aggregates made with clay.

Besides current uses, including composting, soil amendment, animal feed, OP can be considered a valuable source of bioactive substances with well-recognized benefits for human health and well-being. As aforementioned, it is rich in phenolic compounds and triterpenic acids, for which numerous biological activities, including anti-inflammatory, antitumor, antimicrobial, antioxidant, antidiabetic, and cardio-protective activities, have been reported [58]. Among bioactive phenols, hydroxytyrosol (HT) stands out among compounds with highest added value that can be recovered from the solid by-product, due to its high oxidative stability and antioxidant activity and it is currently used as a therapeutic agent, dietary supplement or natural ingredient in food and feed industries. For instance, various contents (65-195 $\mu \mathrm{g}$ ) of HT were added to $100 \mathrm{~g}$ of fresh prepared mayonnaise and several quality parameters as free acidity, peroxide value and concentration of conjugated dienes, as well as the content of polyphenols and squalene in the lipid fraction [59], were evaluated [60]. The authors demonstrated that HT improves the mayonnaise hydrolytic stability reducing the formation of oxidation by-products during storage at room temperature and in the dark up to four weeks. Antioxidant-rich extracts from olive mill pomace related to tree different cultivars of Southern Italy (Nocellara, Roggianella and (Carolea) were dissolved in a commercial pear juice using inulin as a carrier system of bioactive compounds [61]. In vitro evaluation highlighted outstanding antioxidant features of fortified juice in terms of both antioxidant and scavenging performances, representing an attractive source of functional foods. Very recently, Di Nunzio et al. [62] prepared 
bakery products (biscuits and breads) using a variety of flours and fermentation protocols also enriched with defatted OP. To assess the effects in a biological system, the digested fractions were supplemented to intestinal cultured enterocytes cells, used as model system, and the secretion of cytokines was measured. OP extracts were also marketed as feed additives, especially fish feed [63], while an olive oil bioactive extract was tested in fish diet, favouring growth of rainbow trout and gilthead sea bream [64]. Other important examples of the use of by-products for functional and food applications have been summarized by Nunes et al. [65] in a more focused review.

As shown in Figure 1, OMWW (also called alpechin) is a secondary product of the olive oil extraction process generated from three-phase decanters. It has a distinctive odour, $\mathrm{pH}=4.0-5.5$, and high electrical conductivity $(6000-16000 \mathrm{mS} / \mathrm{cm})$; it also contains large amounts of suspended solids and high concentrations of polyaromatic compounds [66]. Despite the fact that three-phase centrifugation causes the reduction of natural antioxidants in olive oil and a considerable volume of OMWW, it is currently largely used for oil production, having high working capacity and enabling the automation of industrial plants, leading to a lessening of manual labour and olive-processing costs [67]. The physicochemical features of OMWW largely depends on the oil extraction and processing methods, climate, as well as olives maturity, cultivar and origin [68-70]. From the chemical composition point of view, OMWW consists mainly of water (80-92\%), and contains 3-15\% organic matter (olive oils, carbohydrates, lipids, pectin, organic acids, polysaccharides, phenols, tannins, and lignin) and minerals [71]. Phenolic compounds, sugars, and organic acids are the main components of the OMWW organic fraction, while, among minerals, the potassium ion content is relatively high (see Table 1 in Ref. [5]). Long-chain fatty acids contained in OMWW represent a pollution concern, being toxic to soil micro-organisms and plants [68] it is considered the most polluting waste generated by the agri-food industries [71]. Although it has been spread for many years into soil or nearby streams and rivers, OMWW can be very harmful to soil microflora, plants and freshwater species [72] since it is characterized by high values for key pollution parameters, such as biological oxygen demand $\left(\mathrm{BOD}_{5}, 40-95 \mathrm{~g} / \mathrm{L}\right)$ and chemical oxygen demand (COD, 50-180 g/L) and high concentrations of phenols and flavonoids (from 0.5 to $24 \mathrm{~g} / \mathrm{L}$ ), having strong antimicrobial and phytotoxic properties [73]. At present, more than 50 different phenolic compounds, in particular hydrophilic species such as phenolic alcohols and acids and, at in a minor amount, secoiridoids, have been identified in OMWW [74-77]. Due to its inherent features and with the aim of giving value to a waste, different employments of OMWW have been evaluated in the last 30 years.

The effects of spreading OMWW on soil properties and crops was reviewed by Barbera et al. [78]; within the European Union each State has established different limits (for example, in Italy the legal limit is $80 \mathrm{~m}^{3} / \mathrm{ha}$ ) and the authors, by using an holistic approach, concluded that direct application of OMWW exerts a temporary positive effect on soil physical properties, if some outlined restrictions based on soil characteristics are applied. Moreover, they emphasized that polyphenols are the most limiting factor for spreading OMWW on soils because of their antimicrobial and phytotoxic effects [78].

Due to the well-known beneficial effects of phenols contained in OMWW, its potential application for the preparation of functional beverages has been also explored [67]. However, some issues were evidenced, such as the stability of bioactive constituents during preservation procedures, processing, and storage that require appropriate thermal and light-exposure conditions. Moreover, as already discussed, the OMWW composition largely depends on specific factors, which makes a "standardization" of its phenolic extract not straightforward. Olive oils enriched with phenolic compounds extracted from OMWW have been also proposed [79-81]; despite further studies are needed, this is an intriguing example of the possibility to create added value by using a waste of olive oil production. As reviewed by Caporaso et al. [81], a similar approach was used for milk and derivatives and also for meat-based products, such as lard and hamburgers. 


\section{Structural Characterization of Phenolic Bioactive Compounds in Waste Products \\ 3.1. Olive Leaves}

The history of studies aiming at the structural characterization of phenolic bioactive compounds in olive leaves is more than 60 years old, with the first structural investigation dating back to 1960, when Panizzi et al. [82] established that the most abundant phenolic compound in olive leaves, initially isolated by Bourquelot and Vintilesco in 1908 and named oleuropein [83], was an ester of HT and elenolic acid glucoside; this last is a carboxylic acid belonging to the class of secoiridoids (see Figures 2 and 3). This research came almost a decade after one of the first studies evidencing, on a scientific basis, the positive effects exerted on human health by olive leaves infusions or decoctions [84]. In the 1970s, Inouye et al. used NMR spectroscopy to describe the structures and assign the absolute configurations of oleuropein and of other secoiridoids found in leaves of different plants, namely loganin and nuzhenide (see Figures 2 and 3), opening the way to the first GC-MS systematic investigation on many secoiridoids and iridoid glucosides [85-87]. Indeed, 33 secoiridoids and iridoid glucosides present in leaves of Paederia scandes and Lonicera morrowii, plants belonging to the Rubiaceae and Caprifoliaceae families, respectively, were characterized. A method for the correct assignment of chromatographic peaks to iridoid/secoiridoid glucosides, was established by the same authors. Among further phenolic compounds existing in olive leaves, also belonging to the class of secoiridoids, ligstroside and demethyloleuropein (with the latter corresponding to oleuropein missing the methyl group linked to the carboxylic moiety bonded to $C^{4}$, see Figure 2) were reported for the first time in 1973 [88], whereas the aglyconic forms of the main secoiridoids of olive leaves were explored by NMR in 1986 by Gariboldi et al. [89]. In the same study, the release of elenolic acid glucoside by acid hydrolysis of oleuropein was proposed, thus confirming the isolation procedure of Panizzi et al. [82]. NMR chemical shifts confirmed a previous spectroscopic investigation dealing with the structure and absolute stereochemistry of elenolic acid [90]. In 1988, Kuwajima et al. [91] isolated oleuroside, another glycosidic secoiridoid from olive leaves; NMR spectroscopy showed that it was an isomer of oleuropein having a 8,10-exocyclic functionality instead of the 8,9 one characteristic of oleuropein and ligstroside (see structures reported in Figure 2 for these secoiridoids with carbon atoms numbering conventionally adopted for them). Notably, the first application of MS was based on fast atom bombardment (FAB), which currently is an unused soft ionization source, to structurally characterize glycosidic secoiridoids as monoprotonated adducts. In subsequent years, FAB-MS using glycerol as matrix was successfully applied to identify the occurrence of oleuropein and its aglycones, obtained by chemical and enzymatic hydrolysis [92], along with flavonoids extracted from olive leaves [40].

To simplify the complexity of phenolic compounds, most of these investigations required several isolation steps from the raw extracts, which may lead to unwanted side reactions of plant tissue metabolites. For this reason, a reliable method for the direct analysis of the olive leaf extract was searched for. In 1997, De Nino et al. [93] set up the first method of direct detection and identification of olive leaves metabolites by MS, with the aim to provide a cultivar "chemical labelling" and a fast non-destructive method to identify biologically and pharmacologically important phenols. Ionspray ionization (ISI, which was the name given at that time to pneumatically assisted electrospray ionization) and FAB were explored to obtain positive ion mass spectra of methanolic extracts of fresh olive foliage. ISI generally led to the generation of protonated molecules, but adducts involving calcium, ammonium or alkali metal ions were also detected, even in the absence of added salts including them as cations. In the case of oleuropein (nominal molecular mass, $540 \mathrm{Da})$, the ISI mass spectrum displayed peaks at $\mathrm{m} / \mathrm{z}$ ratios $541(7 \%), 558(100 \%)$ and $563(42 \%)$, assigned respectively to $[\mathrm{M}+\mathrm{H}]^{+},\left[\mathrm{M}+\mathrm{NH}_{4}\right]^{+}$and $[\mathrm{M}+\mathrm{Na}]^{+}$species. Proton and ammonium adducts were selected as precursor ions for low-energy collisional induced dissociation (CID) tandem mass spectrometry (MS/MS) experiments, leading to similar fragmentation patterns. Intense signals related to ammonium adducts were found in FAB mass spectra of secoiridoid glucosides. Using the same analytical approach, ligstroside and 
diglycosidic secoiridoids, like nuzhenide (see Figure 2), were also easily identified in the crude extract of olive leaves [93].
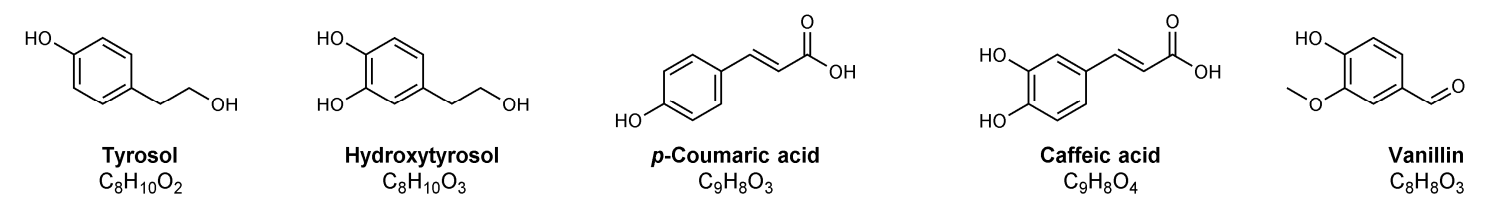

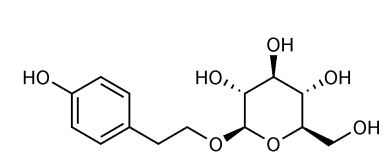

Tyrosol glucoside
$\mathrm{C}_{14} \mathrm{H}_{20} \mathrm{O}_{7}$

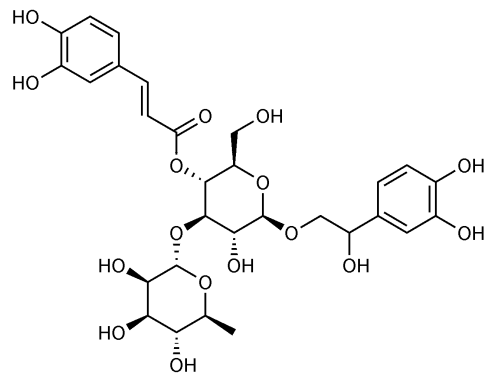

$\beta$-hydroxy-verbascoside $\mathrm{C}_{29} \mathrm{H}_{36} \mathrm{O}_{16}$<smiles>O=c1cc(-c2ccc(O)cc2)oc2cc(O)cc(O)c12</smiles>
Apigenin
$\mathrm{C}_{15} \mathrm{H}_{10} \mathrm{O}_{5}$

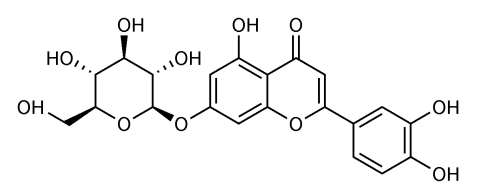

Luteolin-7-O-Glucoside

$$
\mathrm{C}_{21} \mathrm{H}_{20} \mathrm{O}_{11}
$$<smiles>C[C@H]1O[C@H](OC[C@H]2O[C@@H](Oc3c(-c4ccc(O)c(O)c4)oc4cc(O)cc(O)c4c3=O)[C@H](O)[C@H](O)[C@H]2O)[C@H](O)[C@@H](O)[C@H]1O</smiles>

Rutin
$\mathrm{C}_{27} \mathrm{H}_{30} \mathrm{O}_{13}$<smiles>OC[C@H]1O[C@H](OCCc2ccc(O)c(O)c2)[C@H](O)[C@H](O)[C@H]1O</smiles>
Hydroxytyrosol glucoside
\[ \mathrm{C}_{14} \mathrm{H}_{20} \mathrm{O}_{8} \]

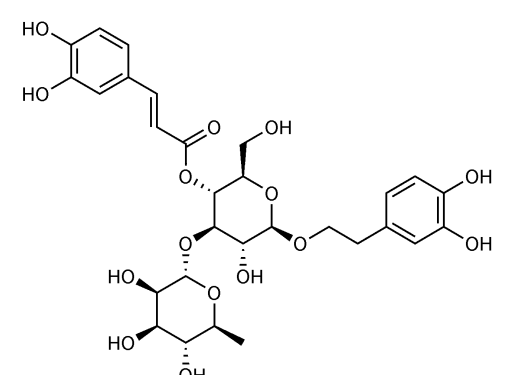

ŌH

Verbascoside $\mathrm{C}_{29} \mathrm{H}_{36} \mathrm{O}_{15}$<smiles>O=c1cc(-c2ccc(O)c(O)c2)oc2cc(O)cc(O)c12</smiles>

Luteolin
$\mathrm{C}_{15} \mathrm{H}_{10} \mathrm{O}_{6}$<smiles>O=c1cc(-c2ccc(O[C@@H]3O[C@H](CO)[C@@H](O)[C@H](O)[C@H]3O)c(O)c2)oc2cc(O)cc(O)c12</smiles>

Luteolin-4'-O-Glucoside $\mathrm{C}_{21} \mathrm{H}_{20} \mathrm{O}_{11}$<smiles>O=c1c(O[C@@H]2O[C@H](CO)[C@@H](O)[C@H](O)[C@H]2O)c(-c2ccc(O)cc2)oc2cc(O)cc(O)c12</smiles>

Kaempferol-3-O-Glucoside $\mathrm{C}_{21} \mathrm{H}_{20} \mathrm{O}_{11}$<smiles>COC(=O)C1=CO[C@@H](O[C@@H]2O[C@H](CO)[C@@H](O)[C@H](O)[C@H]2O)C2C1C[C@@H](C)[C@H]2C</smiles>

Quinic acid

$\mathrm{C}_{7} \mathrm{H}_{12} \mathrm{O}_{6}$<smiles>O=c1c(O)c(-c2ccc(O)c(O)c2)oc2cc(O)cc(O)c12</smiles>

Quercetin
$\mathrm{C}_{15} \mathrm{H}_{10} \mathrm{O}_{7}$

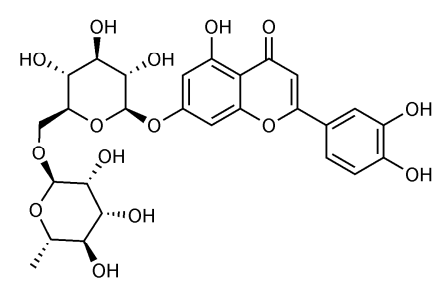

Luteolin-7-O-Rutinoside $\mathrm{C}_{27} \mathrm{H}_{30} \mathrm{O}_{15}$

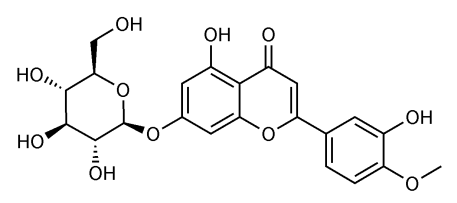

Diosmetin-7-O-Glucoside $\mathrm{C}_{22} \mathrm{H}_{22} \mathrm{O}_{11}$

Figure 3. Structures of bioactive compounds, different from secoiridoids, identified in olive leaves, pomace and in olive oil mill wastewater by MS. Compounds belonging to the classes of phenolic glucosides, simple phenols and flavonoids are indicated. For an extended list of bioactive compounds, see Table 2. 
The increasing significance of electrospray ionization (ESI) and atmospheric pressure chemical ionization (APCI) as soft ionization sources became the key to couple high performance liquid chromatography (HPLC) and MS with the aim to detect bioactive compounds in olive leaves extracts. Verbascoside, rutin, luteolin-7-O-glucoside, oleuropein and HT (see Figures 2 and 3) were thus detected in olive leaves from three different Portugal cultivars by HPLC-APCI-MS based on an ion trap analyser [94]. Oleuropein and ligstroside, among secoiridoids, and the following compounds: flavonol glycosides (quercetin-3O-rutinoside, quercetin-3,7-O-dirhamnoside, kaempferol-3-O-glucoside and kaempferol3-O-glucoside-rhamnoside), flavone glycosides (apigenin-7-O-rutinoside, apigenin-7-Oglucoside, diosmetin-7-O-glucoside) and anthocyanins (peonidin-3-O-rutinoside, cyanidin3-O-rutinoside), for which representative structures are reported in Figure 3, were identified by LC-ESI-MS based on a quadrupole mass spectrometer in leaves of different olive cultivars harvested in Italy [95]. Interestingly, quantitative estimates of oleuropein content, ranging between 0.13 and $21.34 \mathrm{~g} / \mathrm{kg}$ of leaves, according to shoot type, tree age, and period of collection were reported for the Leccino olive cultivar.

Lujan et al. used LC-ESI-MS/MS relying on a triple quadrupole mass spectrometer to evaluate nutraceuticals extracted from olive-trees [96], and quantitative estimates were reported for some of them, those for which standards were available (see Table 3). Raw extracts of olive leaves were investigated by Goulas et al. [97] for antioxidant potency, screened for antiproliferative activity in endothelial and in two cancer cell lines and analyzed by LC-ESI-MS to identify their major components, namely, HT, luteolin-7O-glucoside, luteolin-4'-O-glucoside (see Figure 3), oleuropein, luteolin and HT-acetate, that were also quantified (see Table 3). The concomitant variation of olive-leaf phenolic composition during maturation and its influence on the antioxidant capacity was assessed by LC-ESI-MS analyses of young and mature Olea europaea L. leaves. Sample extracted by dichloromethane, ethyl acetate and methanol were examined by ESI-MS and MS/MS based on a quadrupole ion trap spectrometer [98]. Apparently, mature olive-leaf extracts contained higher levels of verbascoside isomers and glycosidic forms of luteolin, while higher contents of oleuropein, ligstroside, and flavonoid aglycones were present in young leaves [98]. A qualitative screening of phenolic compounds in olive leaf extracts by HPLCESI coupled to time-of-flight MS instrument (TOF-MS) and ion trap tandem mass spectrometry (ESI-IT-MS ${ }^{2}$ ) was subsequently performed by Fu et al. [99]. In conjunction with LC, the same approaches were exploited to characterize the olive leaf phenolics extracted by microwaves assistance [100]. A similar approach was reported by Quirantes-Piné et al. [101] using a hybrid QTOF-MS instrument with preliminary HPLC separation and an extended investigation on phenolic compounds in leaves of Spanish olive cultivars by LC-ESI-TOFMS was described by Talhoui et al., with a detailed comparative quantification of several compounds (see Table 3 for the respective values) [102]. Tandem MS was successfully utilized in other studies dealing with the profiling of olive leaves phenolics extracts [103-105]. In 2018, Olmo-Garcia et al. studied the distribution of the main secondary metabolites found in Olea europaea L., including phenolic compounds, by LC-QTOF-MS (coupled with ESI and/or APCI) and GC-APCI-QTOF-MS [106]. Eight different sample types (olive leaf, stem, seed, fruit skin and pulp, as well as virgin olive oil, olive oil obtained from stoned and dehydrated fruits and olive seed oil) related to the Picudo olive cultivar were analyzed. More than 130 metabolites were discovered. The suitability of each platform and polarity (negative/positive) to determine every family of metabolites was evaluated in-depth considering the oil extract from stoned and dehydrated olives, since these matrices contained the major number of compounds. The LC-ESI platform operated in positive ionization mode produced the highest ionization rates for phenolic acids and aldehydes, secoiridoids and derivatives, flavonoids and lignans, therefore indicating LC-ESI(+)-MS as the most efficient choice to ionize these classes of compounds. GC-APCI-MS was the best option for the detection of simple phenols and fatty acids-related metabolites [106].

In recent years, the use of high resolution/accuracy MS, based on the orbital trap FT mass analysers, has opened interesting perspectives for an even deeper structural 
characterization of bioactive phenolic compounds related to the olive plant. In 2013, Kanakis et al. [107] proposed an HPLC-FTMS study using an Orbitrap analyzer for the identification and quantification of bioactive compounds in olive drupes and olive oils. Michel et al. used the same analytical approach for an extended investigation on olive leaves metabolites, with 86 compounds identified, including coumarin, described for the first time in O. europaea [108]. The presence of functional compounds in different Greek varieties of olive leaves and drupes was assessed by Kritikou et al. using reversed-phase LC coupled to high resolution mass spectrometry [109].

More recently, a detailed characterization of the complex set of isomeric forms found for major secoiridoids present in olive oil has been reported by Abbattista et al. using an hybrid quadrupole-Orbitrap mass spectrometer, capable of high collisional energy MS/MS analyses under high resolution/accuracy conditions, and implementing H/D exchange experiments to recognize stable enolic tautomers related to aglyconic secoiridoids $[110,111]$. The described approach appears very promising for the search for isomeric secoiridoids also in olive leaves extracts.

All above mentioned phenolic compounds, including phenolic acids (like $p$-coumaric and caffeic, see Figure 3), phenolic alcohols (HT and tyrosol), flavonoids (luteolin 7-Oglucoside, luteolin 4-O-glucoside, rutin, apigenin 7-O-glucoside), and oleuropein, among phenolic secoiridoids, represent key components of olive leaves, in accordance with the fact that leaves are important sites of plant primary and secondary metabolism [112]. Many of these compounds play fundamental roles for plant sustenance and defense mechanisms. In particular, oleuropein is one of the most important bioactive compounds present in olive leaves [112], with antioxidative, antimicrobial [113], antiviral (even against the HIV virus [114]), cardioprotective [115], antihypertensive [116] and anti-inflammatory hallmarks [117]. Hypocholesterolemic [118] and hypoglycemic [119] activities, together with the lipid metabolism enhancement effect, potentially useful to alleviate obesity [120], have been also attested in the literature. The role of oleuropein as a mitigating agent for kidney injury induced by the well-known anti-tumoral drug cisplatin, through conjugate generation, has been explored by LC-ESI-MS/MS [121].

As evidenced by data reported in Table 3 and in a further reference [122], oleuropein is, by far, the most abundant bioactive compound in olive leaves, although significant differences can be observed between cultivars. It is, thus, not surprising that the isolation and subsequent chemical characterization of oleuropein by MS has become increasingly important in view of its inclusion in foodstuffs or in other types of products, as explained before. It is worth noting, however, that, although nutraceutical formulations have a very distinctive antioxidant capacity and a greater concentration of oleuropein compared to simple leaf extracts, the effects of the pure substance may be limited by its hydrolytic cleavage during purification steps. The use of olive leaf extracts without isolating the major constituent might thus be recommended to achieve the best healthy properties, thanks to the synergy of all bioactive compounds occurring in the extracts, which most likely affect their absorption and bioavailability [13]. As evidenced in Table 3, other secoiridoids, phenolic or not, like ligstroside, oleuroside, secologanoside, verbascoside, demethyloleuropein and methoxyoleuropein, are usually present in amounts of some $\mathrm{g}$ per $\mathrm{kg}$ of olive leaves. Notably, secoiridoids like oleuropein stand out among natural compounds synthesized by plants of the Oleaceae family also for their role as precursors of phytoalexins, i.e., compounds used as chemical weapons against pathogen attacks, like the corresponding aglycones [123-125], thus their isolation might open new interesting perspectives of application.

As for other potentially bioactive compounds for which a quantification has been reported so far in olive leaves, thanks to the availability of the corresponding standards, data reported in Table 3 indicate flavonoids, as such or as glucosides, especially luteolin-4'$\mathrm{O}$-glucoside, to be generally present in amounts of several $\mathrm{g}$ per $\mathrm{kg}$ of olive leaves, that would encourage the possibility of extracting them for subsequent applications. 


\subsection{Olive Pomace (OP) and Olive Oil Mill Wastewater (OOMW)}

By analogy with olive leaves, bioactive phenolic compounds can occur in OP [126]. A summary of the most important bioactive compounds identified so far in olive leaves, OP and OOMW using MS techniques is reported in Table 2.

Table 2. List of the most important bioactive compounds detected using mass spectrometry in olive leaves and olive pomace and in olive oil mill wastewater (OOMW).

\begin{tabular}{|c|c|c|c|c|c|c|c|}
\hline Name & Formula (M) & $\begin{array}{c}m / z \\
{[\mathrm{M}-\mathrm{H}]^{-}}\end{array}$ & $\begin{array}{c}m / z \\
{[\mathbf{M}+\mathbf{H}]^{+}}\end{array}$ & $\begin{array}{l}\text { Ionization } \\
\text { Source }\end{array}$ & Leaves & Olive Pomace & OOMW \\
\hline 10-hydroxy-oleacin & $\mathrm{C}_{17} \mathrm{H}_{20} \mathrm{O}_{7}$ & 335.114 & 337.128 & APCI, ESI & {$[106]^{5}$} & [49] & \\
\hline 10-hydroxy-oleuropein & $\mathrm{C}_{25} \mathrm{H}_{32} \mathrm{O}_{14}$ & 555.172 & & ESI & [100] & [127] & \\
\hline $\begin{array}{l}\text { 10-hydroxyoleuropein } \\
\text { aglycone }\end{array}$ & $\mathrm{C}_{19} \mathrm{H}_{22} \mathrm{O}_{9}$ & 393.120 & 395.133 & APCI, ESI & {$[106]^{5}$} & & \\
\hline $\begin{array}{c}\text { 1- } \beta \text {-D-glucopyranosyl } \\
\text { acyclodihydroelenolic acid } \\
\text { glycosylate }\end{array}$ & $\mathrm{C}_{23} \mathrm{H}_{28} \mathrm{O}_{16}$ & 569.209 & & ESI & & [128] & \\
\hline $\begin{array}{c}\text { 1- } \beta \text {-D- } \\
\text { glucopyranosylacyclodihydro } \\
\text { elenolic acid } \\
\text { (acyclodihydroelenolic acid } \\
\text { hexoside) }\end{array}$ & $\mathrm{C}_{17} \mathrm{H}_{28} \mathrm{O}_{11}$ & 407.156 & 409.17 & APCI, ESI & {$[106]^{5}$} & [128] & \\
\hline $\begin{array}{l}\text { 2-(2-ethyl-3-hydroxy-6- } \\
\text { propionylcyclohexyl) acetic } \\
\text { acid glucoside }\end{array}$ & $\mathrm{C}_{19} \mathrm{H}_{32} \mathrm{O}_{9}$ & 403.197 & & ESI & [100] & & \\
\hline 2-hydroxy-oleuropein & $\mathrm{C}_{25} \mathrm{H}_{32} \mathrm{O}_{14}$ & 555.172 & & ESI & & [129] & \\
\hline 2-phenethyl- $\beta$-primeveroside & $\mathrm{C}_{19} \mathrm{H}_{28} \mathrm{O}_{10}$ & 415.161 & 417.175 & APCI, ESI & {$[106]^{5}$} & & \\
\hline 3,4-dihydroxyphenylglycol & $\mathrm{C}_{8} \mathrm{H}_{10} \mathrm{O}_{4}$ & $151.040^{\mathrm{d}}$ & $153.054^{\mathrm{a}}$ & $\begin{array}{l}\text { APCI, ESI, } \\
\text { MALDI }\end{array}$ & {$[106]^{5}$} & & {$[76]^{1}$} \\
\hline 4-hydroxyphenylacetic acid & $\mathrm{C}_{8} \mathrm{H}_{8} \mathrm{O}_{3}$ & 151.040 & 153.054 & APCI, ESI & {$[106]^{5}$} & [130] & \\
\hline $\begin{array}{l}6^{\prime}-\beta \text {-rhamnopyranosyl- } \\
\text { oleoside }\end{array}$ & $\mathrm{C}_{22} \mathrm{H}_{32} \mathrm{O}_{15}$ & 535.167 & & ESI & & [130] & \\
\hline $\begin{array}{l}\text { 6'-O-[2,6-dimethyl-8-hydroxy- } \\
\text { 2-octenoyloxy]-secologanoside }\end{array}$ & $\mathrm{C}_{26} \mathrm{H}_{38} \mathrm{O}_{13}$ & 557.224 & & ESI & [101] & & \\
\hline 7-deoxyloganic acid & $\mathrm{C}_{16} \mathrm{H}_{24} \mathrm{O}_{9}$ & 359.135 & & ESI & [108] & [127] & \\
\hline Acteoside & $\mathrm{C}_{29} \mathrm{H}_{36} \mathrm{O}_{15}$ & 623.198 & & ESI & [103] & & \\
\hline Acetoxypinoresinol & $\mathrm{C}_{22} \mathrm{H}_{24} \mathrm{O}_{8}$ & 415.139 & & ESI & [100] & [131] & \\
\hline $\begin{array}{c}\text { Aesculetin } \\
\text { (Dihydroxhycoumarin } \\
\text { isomers) }\end{array}$ & $\mathrm{C}_{9} \mathrm{H}_{6} \mathrm{O}_{4}$ & 177.019 & 179.034 & APCI, ESI & {$[106]^{5}[108]$} & & \\
\hline Aesculin & $\mathrm{C}_{15} \mathrm{H}_{16} \mathrm{O}_{9}$ & 339.072 & 341.088 & APCI, ESI & {$[106]^{5}$} & & \\
\hline Apigenin & $\mathrm{C}_{15} \mathrm{H}_{10} \mathrm{O}_{5}$ & 269.046 & 271.06 & APCI, ESI & $\begin{array}{c}{[9]^{3}[100][106]^{5}} \\
{[108,109]}\end{array}$ & {$[96,127,131-133]$} & [133] \\
\hline $\begin{array}{l}\text { Apigenin 6,8-di-C-glucoside } \\
\text { (Vicenin 2) }\end{array}$ & $\mathrm{C}_{27} \mathrm{H}_{30} \mathrm{O}_{15}$ & 593.151 & & ESI & [7] & & \\
\hline Apigenin-7-O-glucoside & $\mathrm{C}_{21} \mathrm{H}_{20} \mathrm{O}_{10}$ & 431.098 & 433.113 & APCI, ESI, FAB & $\begin{array}{c}{[7][9]^{3}} \\
{[99-101,105]} \\
{[106]^{5}[108]}\end{array}$ & {$[96,127,131,133]$} & [133] \\
\hline Apigenin-7-O-rutinoside & $\mathrm{C}_{27} \mathrm{H}_{30} \mathrm{O}_{14}$ & 577.156 & 579.171 & APCI, ESI & $\begin{array}{c}{[7,23,100-102]} \\
{[106]^{5}[108]}\end{array}$ & & [134] \\
\hline Ascorbyl hexoside & $\mathrm{C}_{12} \mathrm{H}_{18} \mathrm{O}_{11}$ & 337.078 & & ESI & [7] & & \\
\hline Azelaic acid & $\mathrm{C}_{9} \mathrm{H}_{16} \mathrm{O}_{4}$ & 187.097 & 189.113 & APCI, ESI & {$[106]^{5}$} & & \\
\hline$\beta$-hydroxy-isoverbascoside & $\mathrm{C}_{29} \mathrm{H}_{36} \mathrm{O}_{16}$ & 639.193 & & ESI & {$[7,108]$} & {$[128,129]$} & {$[135,136]$} \\
\hline$\beta$-hydroxyacteoside & $\mathrm{C}_{29} \mathrm{H}_{36} \mathrm{O}_{16}$ & 639.193 & & ESI & & [129] & \\
\hline$\beta$-methoxyl-verbascoside & $\mathrm{C}_{30} \mathrm{H}_{38} \mathrm{O}_{16}$ & 653.209 & & ESI & [108] & & \\
\hline Caffeic acid & $\mathrm{C}_{9} \mathrm{H}_{8} \mathrm{O}_{4}$ & 179.035 & 181.05 & APCI, ESI & {$[103,105][106]^{5}$} & {$[49,127,131]$} & {$[134,136]$} \\
\hline Caffeic acid derivative & $\mathrm{C}_{18} \mathrm{H}_{18} \mathrm{O}_{9}$ & 377.089 & & ESI & [103] & & \\
\hline Caffeic acid diglycoside & $\mathrm{C}_{21} \mathrm{H}_{30} \mathrm{O}_{13}$ & 489.161 & & ESI & [108] & & \\
\hline Caffeic alcohol derivative & $\mathrm{C}_{21} \mathrm{H}_{30} \mathrm{O}_{13}$ & 489.161 & & ESI & [103] & & \\
\hline $\begin{array}{c}\text { Caffeoyl-6'-secologanoside } \\
\text { (Cafselogoside) }\end{array}$ & $\mathrm{C}_{25} \mathrm{H}_{28} \mathrm{O}_{14}$ & 551.141 & 553.155 & APCI, ESI & {$[106]^{5}$} & {$[49,50,133]$} & {$[133,134]$} \\
\hline Caffeoyl-hexoside & $\mathrm{C}_{15} \mathrm{H}_{18} \mathrm{O}_{9}$ & 341.088 & & ESI & & [49] & \\
\hline Calceolarioside & $\mathrm{C}_{23} \mathrm{H}_{26} \mathrm{O}_{11}$ & 477.14 & & ESI & {$[7,108]$} & [49] & \\
\hline
\end{tabular}


Table 2. Cont

\begin{tabular}{|c|c|c|c|c|c|c|c|}
\hline Name & Formula (M) & $\begin{array}{c}m / z \\
{[\mathrm{M}-\mathrm{H}]^{-}}\end{array}$ & $\begin{array}{c}m / z \\
{[\mathrm{M}+\mathrm{H}]^{+}}\end{array}$ & $\begin{array}{l}\text { Ionization } \\
\text { Source }\end{array}$ & Leaves & Olive Pomace & OOMW \\
\hline $\begin{array}{c}\text { Chlorogenic acid } \\
\text { (Caffeoyl-quinic acid) }\end{array}$ & $\mathrm{C}_{16} \mathrm{H}_{18} \mathrm{O}_{9}$ & 353.088 & 355.102 & ESI & {$[7,105]$} & {$[49,130]$} & [134] \\
\hline Chrysoeriol & $\mathrm{C}_{16} \mathrm{H}_{12} \mathrm{O}_{6}$ & 299.056 & 301.071 & ESI & & & [134] \\
\hline Chrysoeriol-7-O-glucoside & $\mathrm{C}_{22} \mathrm{H}_{22} \mathrm{O}_{11}$ & 461.109 & 463.124 & APCI, ESI & $\begin{array}{l}{[7,99,100,102]} \\
{[106]^{5}}\end{array}$ & & \\
\hline Cinammic acid & $\mathrm{C}_{9} \mathrm{H}_{8} \mathrm{O}_{2}$ & 147.045 & & ESI & & [127] & \\
\hline Citric acid & $\mathrm{C}_{6} \mathrm{H}_{8} \mathrm{O}_{7}$ & 191.02 & $175.024^{a}$ & APCI, ESI & {$[7][106]^{5}$} & & \\
\hline Comselogoside & $\mathrm{C}_{25} \mathrm{H}_{27} \mathrm{O}_{13}$ & 535.146 & 537.16 & APCI, ESI & {$[106]^{5}$} & {$[49,50,133]$} & $\begin{array}{c}{[133,134} \\
136]\end{array}$ \\
\hline Cyanidin-3-rutinoside & $\mathrm{C}_{27} \mathrm{H}_{31} \mathrm{O}_{15}{ }^{+}$ & & 595.166 & ESI & [95] & & \\
\hline $\begin{array}{l}\mathrm{D}(+) \text {-Erytro-1-(4-hydroxy-3- } \\
\text { methoxy)-phenyl-1,2,3- } \\
\text { propantriol }\end{array}$ & $\mathrm{C}_{10} \mathrm{H}_{14} \mathrm{O}_{5}$ & 213.077 & 215.091 & ESI & & [50] & [134] \\
\hline Decaffeoyl verbascoside & $\mathrm{C}_{20} \mathrm{H}_{30} \mathrm{O}_{12}$ & 461.166 & & ESI & [7] & [49] & \\
\hline Dehydro ligstroside aglycone & $\mathrm{C}_{19} \mathrm{H}_{20} \mathrm{O}_{7}$ & 359.114 & 361.129 & APCI, ESI & {$[106]^{5}$} & & \\
\hline Dehydro oleuropein aglycone & $\mathrm{C}_{19} \mathrm{H}_{20} \mathrm{O}_{8}$ & 375.109 & 377.124 & APCI, ESI & {$[106]^{5}$} & & \\
\hline Demethyloleuropein & $\mathrm{C}_{24} \mathrm{H}_{30} \mathrm{O}_{13}$ & 525.161 & & ESI & {$[7,99,102,108]$} & {$[132,133]$} & [133] \\
\hline Deoxyloganic acid lauryl ester & $\mathrm{C}_{23} \mathrm{H}_{38} \mathrm{O}_{5}$ & 393.264 & & ESI & & [137] & \\
\hline Desoxyelenolic acid & $\mathrm{C}_{11} \mathrm{H}_{14} \mathrm{O}_{5}$ & 225.077 & 227.091 & APCI, ESI & {$[106]^{5}$} & & \\
\hline Dihydro-oleuropein & $\mathrm{C}_{25} \mathrm{H}_{36} \mathrm{O}_{13}$ & 543.208 & & APCI, ESI & {$[7][106]^{5}$} & {$[49,127,128,133]$} & [133] \\
\hline Dihyroxybenzoic acid hexoside & $\mathrm{C}_{13} \mathrm{H}_{16} \mathrm{O}_{9}$ & 315.072 & & ESI & [7] & & \\
\hline $\begin{array}{l}\text { Dihyroxybenzoic acid hexoside } \\
\text { pentoside }\end{array}$ & $\mathrm{C}_{18} \mathrm{H}_{24} \mathrm{O}_{13}$ & 447.114 & & ESI & [7] & & \\
\hline Dimethyl oleuropein aglycone & $\mathrm{C}_{21} \mathrm{H}_{26} \mathrm{O}_{8}$ & 405.156 & 407.17 & APCI, ESI & {$[106]^{5}$} & & \\
\hline Diosmetin & $\mathrm{C}_{16} \mathrm{H}_{12} \mathrm{O}_{6}$ & 299.056 & 301.071 & APCI, ESI & $\begin{array}{c}{[98,100][106]^{5}} \\
{[108]}\end{array}$ & [127] & \\
\hline Diosmetin glucoside & $\mathrm{C}_{22} \mathrm{H}_{22} \mathrm{O}_{11}$ & 461.109 & & ESI & [108] & & \\
\hline Diosmin & $\mathrm{C}_{28} \mathrm{H}_{32} \mathrm{O}_{15}$ & 607.167 & & ESI & {$[7,100,108]$} & & \\
\hline Elenolic acid (EA)-methyl ester & $\mathrm{C}_{12} \mathrm{H}_{16} \mathrm{O}_{6}$ & 255.088 & 257.102 & APCI, ESI & {$[106]^{5}$} & & \\
\hline Elenolic acid (EA) & $\mathrm{C}_{11} \mathrm{H}_{14} \mathrm{O}_{6}$ & 241.072 & $243.086,225.077^{\text {a }}$ & $\begin{array}{l}\text { APCI, ESI, } \\
\text { MALDI }\end{array}$ & {$[76]^{1}[106]^{5}$} & {$[49,127,131]$} & $\begin{array}{c}{[134,136,} \\
138]\end{array}$ \\
\hline $\begin{array}{l}\text { Elenolic acid (EA) derivative } \\
\text { (decarboxylated form of } \\
\text { hydroxyelenolic acid) }\end{array}$ & $\mathrm{C}_{10} \mathrm{H}_{14} \mathrm{O}_{5}$ & 213.077 & $197.081^{\mathrm{a}}$ & $\begin{array}{l}\text { APCI, ESI, } \\
\text { MALDI }\end{array}$ & {$[106]^{5}$} & [132] & $\begin{array}{l}{[76]^{1}} \\
{[138]}\end{array}$ \\
\hline Elenolic acid (EA) derivative & $\mathrm{C}_{10} \mathrm{H}_{16} \mathrm{O}_{5}$ & 215.092 & & ESI & & {$[50,132]$} & \\
\hline $\begin{array}{c}\text { Elenolic acid } \\
\text { decarboxymethylated (EDA) }\end{array}$ & $\mathrm{C}_{9} \mathrm{H}_{12} \mathrm{O}_{4}$ & 183.066 & 185.081 & $\begin{array}{l}\text { APCI, ESI, } \\
\text { MALDI }\end{array}$ & {$[106]^{5}$} & [50] & $\begin{array}{c}{[76]^{1}} \\
{[136,138]}\end{array}$ \\
\hline Elenolic acid diglucoside & $\mathrm{C}_{23} \mathrm{H}_{33} \mathrm{O}_{16}$ & 565.177 & & ESI & [101] & & \\
\hline $\begin{array}{l}\text { Elenolic acid glucoside } \\
\text { (Oleoside methyl ester) }\end{array}$ & $\mathrm{C}_{17} \mathrm{H}_{24} \mathrm{O}_{11}$ & 403.125 & 405.139 & $\begin{array}{l}\text { APCI, ESI, } \\
\text { MALDI }\end{array}$ & $\begin{array}{c}{[7][76]^{1}[99-103]} \\
{[106]^{5}[108]}\end{array}$ & {$[127,128,130,133]$} & {$[133,134]$} \\
\hline $\begin{array}{c}\text { Elenolic acid hexoside } \\
\text { derivative }\end{array}$ & $\mathrm{C}_{19} \mathrm{H}_{26} \mathrm{O}_{13}$ & 461.13 & & ESI & [7] & & \\
\hline Eriodictyol & $\mathrm{C}_{15} \mathrm{H}_{12} \mathrm{O}_{6}$ & 287.056 & & ESI & {$[103,105]$} & & \\
\hline Eudesmic acid & $\mathrm{C}_{10} \mathrm{H}_{12} \mathrm{O}_{5}$ & 211.06 & 213.076 & APCI, ESI & {$[106]^{5}$} & & \\
\hline Ferulic acid & $\mathrm{C}_{10} \mathrm{H}_{10} \mathrm{O}_{4}$ & 193.051 & 195.066 & APCI, ESI & {$[103][106]^{5}[109]$} & {$[49,127]$} & \\
\hline Feruloyl-hexoside & $\mathrm{C}_{16} \mathrm{H}_{20} \mathrm{O}_{9}$ & 401.109 & & ESI & & [49] & \\
\hline Flavonol diglicoside & $\mathrm{C}_{27} \mathrm{H}_{30} \mathrm{O}_{16}$ & 609.146 & & ESI & [108] & & \\
\hline Fraxamoside & $\mathrm{C}_{25} \mathrm{H}_{30} \mathrm{O}_{13}$ & 537.161 & & ESI & {$[7,108]$} & & \\
\hline Fustin & $\mathrm{C}_{15} \mathrm{H}_{12} \mathrm{O}_{6}$ & 287.056 & & ESI & [103] & & \\
\hline Gallic acid & $\mathrm{C}_{7} \mathrm{H}_{6} \mathrm{O}_{5}$ & 169.014 & & APCI, ESI & $\begin{array}{c}{[7,105][106]^{5}} \\
{[109]}\end{array}$ & [127] & [138] \\
\hline Gallocatechin & $\mathrm{C}_{15} \mathrm{H}_{14} \mathrm{O}_{7}$ & 305.067 & & APCI, ESI & {$[106]^{5}[108]$} & & \\
\hline Gingerol & $\mathrm{C}_{17} \mathrm{H}_{26} \mathrm{O}_{4}$ & 293.176 & 295.19 & APCI, ESI & {$[106]^{5}$} & & \\
\hline Gluconic acid & $\mathrm{C}_{6} \mathrm{H}_{11} \mathrm{O}_{7}$ & 195.051 & & ESI & [101] & & \\
\hline Homovanillyl alcohol & $\mathrm{C}_{9} \mathrm{H}_{12} \mathrm{O}_{3}$ & 167.071 & & ESI & [103] & & \\
\hline Hydrogenated EDA & $\mathrm{C}_{9} \mathrm{H}_{14} \mathrm{O}_{4}$ & 185.082 & & MALDI & & & {$[76]^{1}$} \\
\hline Hydrogenated-EA & $\mathrm{C}_{11} \mathrm{H}_{16} \mathrm{O}_{6}$ & 243.087 & & ESI & & [50] & \\
\hline
\end{tabular}


Table 2. Cont

\begin{tabular}{|c|c|c|c|c|c|c|c|}
\hline Name & Formula (M) & $\begin{array}{c}m / z \\
{[\mathrm{M}-\mathrm{H}]^{-}}\end{array}$ & $\begin{array}{c}m / z \\
{[\mathrm{M}+\mathrm{H}]^{+}}\end{array}$ & $\begin{array}{l}\text { Ionization } \\
\text { Source }\end{array}$ & Leaves & Olive Pomace & оомw \\
\hline Hydro-oleuropein & $\mathrm{C}_{25} \mathrm{H}_{34} \mathrm{O}_{13}$ & 541.193 & & ESI & & [128] & \\
\hline Hydroxy-oleocanthal & $\mathrm{C}_{17} \mathrm{H}_{20} \mathrm{O}_{6}$ & 319.119 & 321.134 & APCI, ESI & {$[106]^{5}$} & & \\
\hline Hydroxy-EA & $\mathrm{C}_{11} \mathrm{H}_{14} \mathrm{O}_{7}$ & 257.067 & 259.081 & APCI, ESI & {$[106]^{5}$} & & \\
\hline Hydroxy-EDA & $\mathrm{C}_{9} \mathrm{H}_{12} \mathrm{O}_{5}$ & 199.062 & $183.065^{\mathrm{a}}$ & APCI, ESI & {$[106]^{5}$} & {$[49,132]$} & [136] \\
\hline Hydroxy-oleuropein & $\mathrm{C}_{25} \mathrm{H}_{32} \mathrm{O}_{14}$ & 555.172 & & APCI, ESI & $\begin{array}{c}{[7,101,103][106]^{5}} \\
{[108]}\end{array}$ & [132] & \\
\hline Hydroxy-oleuropein aglycone & $\mathrm{C}_{22} \mathrm{H}_{32} \mathrm{O}_{8}$ & 423.202 & & ESI & [108] & & \\
\hline Hydroxypinoresinol & $\mathrm{C}_{20} \mathrm{H}_{22} \mathrm{O}_{7}$ & 373.129 & 375.145 & APCI, ESI & {$[106]^{5}$} & [127] & \\
\hline Hydroxytyrosol (3,4-DHPEA) & $\mathrm{C}_{8} \mathrm{H}_{10} \mathrm{O}_{3}$ & 153.056 & 155.07 & $\begin{array}{l}\text { APCI, ESI, } \\
\text { MALDI }\end{array}$ & $\begin{array}{c}{[94,97,99-101,103]} \\
{[106]^{5}[108,109]}\end{array}$ & $\begin{array}{c}{[49,50,96,127} \\
131-133]\end{array}$ & $\begin{array}{c}\text { [76] }^{1}[133, \\
134,136, \\
138,139]\end{array}$ \\
\hline Hydroxytyrosol acetate & $\mathrm{C}_{10} \mathrm{H}_{11} \mathrm{O}_{4}$ & 195.066 & & ESI & {$[97,101]$} & {$[131,133]$} & [133] \\
\hline Hydroxytyrosol diglucoside & $\mathrm{C}_{20} \mathrm{H}_{28} \mathrm{O}_{13}$ & 475.146 & & ESI & & [127] & \\
\hline Hydroxytyrosol glucoside & $\mathrm{C}_{14} \mathrm{H}_{20} \mathrm{O}_{8}$ & 315.109 & 317.124 & $\begin{array}{l}\text { APCI, ESI, } \\
\text { MALDI }\end{array}$ & $\begin{array}{c}{[7,23][76]^{1}} \\
{[99,102,103,106]^{5}} \\
{[108]}\end{array}$ & {$[49,127,130,133]$} & $\begin{array}{c}{[133,134,} \\
136]\end{array}$ \\
\hline Hydroxytyrosol rhamnoside & $\mathrm{C}_{20} \mathrm{H}_{34013}$ & 481.193 & & ESI & & [127] & \\
\hline $\begin{array}{c}\text { Hydroxytyrosil } \\
\text { acyclodihydroelenolate }\end{array}$ & $\mathrm{C}_{19} \mathrm{H}_{26} \mathrm{O}_{8}$ & 381.156 & 383.17 & ESI & & & {$[134,136]$} \\
\hline Isoacetoside & $\mathrm{C}_{29} \mathrm{H}_{36} \mathrm{O}_{15}$ & 623.198 & 625.213 & ESI & [99] & & [134] \\
\hline Isoverbascoside & $\mathrm{C}_{29} \mathrm{H}_{36} \mathrm{O}_{15}$ & 623.198 & & ESI & [7] & & [135] \\
\hline Jaspolyoside & $\mathrm{C}_{42} \mathrm{H}_{54} \mathrm{O}_{23}$ & 925.298 & & ESI & {$[7,108]$} & & \\
\hline Jaspolyoside derivative & $\mathrm{C}_{42} \mathrm{H}_{54} \mathrm{O}_{22}$ & 909.303 & & ESI & {$[108]$} & & \\
\hline Ligstroside & $\mathrm{C}_{25} \mathrm{H}_{32} \mathrm{O}_{12}$ & 523.128 & $\begin{array}{r}525.197 \\
507.185^{\mathrm{a}} \\
542.223^{\mathrm{b}} \\
\end{array}$ & APCI, ESI, FAB & $\begin{array}{c}{[7,23][93]^{4}} \\
{[98,99,101-103]} \\
{[106]^{5}[108]} \\
\end{array}$ & {$[132,133]$} & {$[133,134]$} \\
\hline $\begin{array}{l}\text { Ligstroside aglycone } \\
(p \text {-HPEA-EA) }\end{array}$ & $\mathrm{C}_{19} \mathrm{H}_{22} \mathrm{O}_{7}$ & 361.129 & 363.144 & APCI, ESI & {$[94,99][106]^{5}$} & {$[127,128,131,133]$} & {$[133,134]$} \\
\hline Loganic acid & $\mathrm{C}_{16} \mathrm{H}_{24} \mathrm{O}_{10}$ & 375.130 & & ESI & [7] & {$[127,132]$} & \\
\hline Loganic acid glucoside & $\mathrm{C}_{22} \mathrm{H}_{33} \mathrm{O}_{16}$ & 537.183 & & ESI & [7] & {$[49,127]$} & \\
\hline Loganin (7-epiloganin) & $\mathrm{C}_{17} \mathrm{H}_{26} \mathrm{O}_{10}$ & 389.145 & & ESI & {$[7,101,108]$} & [127] & \\
\hline Loganin glucoside & $\mathrm{C}_{23} \mathrm{H}_{38} \mathrm{O}_{16}$ & 569.209 & & ESI & & [127] & \\
\hline Lucidumoside C & $\mathrm{C}_{27} \mathrm{H}_{35} \mathrm{O}_{14}$ & 583.203 & & APCI, ESI & {$[101][106]^{5}$} & & \\
\hline Luteolin derivative & $\mathrm{C}_{31} \mathrm{H}_{36} \mathrm{O}_{13}$ & 615.208 & & ESI & [108] & & \\
\hline Luteolin & $\mathrm{C}_{15} \mathrm{H}_{10} \mathrm{O}_{6}$ & 285.041 & 287.055 & APCI, ESI & $\begin{array}{c}{[9]^{3}} \\
{[23,97,99-103,105]} \\
{[106]^{5}[108,109]} \\
\end{array}$ & {$[96,127,130-133]$} & {$[133,134]$} \\
\hline Luteolin derivative & $\mathrm{C}_{31} \mathrm{H}_{28} \mathrm{O}_{14}$ & 623.141 & & ESI & [108] & & \\
\hline Luteolin diglucoside & $\mathrm{C}_{27} \mathrm{H}_{30} \mathrm{O}_{16}$ & 609.146 & 611.161 & APCI, ESI & $\begin{array}{c}{[7,23,100-102]} \\
{[106]^{5}}\end{array}$ & & \\
\hline Luteolin-4'-O-glucoside & $\mathrm{C}_{21} \mathrm{H}_{20} \mathrm{O}_{11}$ & 447.093 & 449.108 & APCI, ESI & {$[94,97,101][106]^{5}$} & {$[130,133]$} & {$[133,134]$} \\
\hline Luteolin-7-O-glucoside & $\mathrm{C}_{21} \mathrm{H}_{20} \mathrm{O}_{11}$ & 447.093 & 449.108 & $\begin{array}{l}\text { APCI, ESI, } \\
\text { MALDI }\end{array}$ & $\begin{array}{c}{[4,7][9]^{3}[76]^{1}} \\
{[94,97,98,101,105]} \\
{[106]^{5}}\end{array}$ & {$[96,128,130-133]$} & {$[133,134]$} \\
\hline Luteolin-7-O-rutinoside & $\mathrm{C}_{27} \mathrm{H}_{30} \mathrm{O}_{15}$ & 593.151 & 595.166 & ESI APCI & [7] [9] ${ }^{3}[101]$ & {$[130,132]$} & [134] \\
\hline Luteolin-hexoside & $\mathrm{C}_{21} \mathrm{H}_{20} \mathrm{O}_{11}$ & 447.093 & 449.108 & APCI, ESI & $\begin{array}{c}{[7,23,99-103]} \\
{[106]^{5}[108]}\end{array}$ & {$[127,132]$} & \\
\hline Luteolin-O-rutinoside & $\mathrm{C}_{27} \mathrm{H}_{30} \mathrm{O}_{15}$ & 593.151 & 595.166 & APCI, ESI & $\begin{array}{c}{[23,100,102][106]^{5}} \\
{[108]}\end{array}$ & {$[49,130,133]$} & [133] \\
\hline Malic acid & $\mathrm{C}_{4} \mathrm{H}_{6} \mathrm{O}_{5}$ & 133.014 & & ESI & [7] & & \\
\hline Maslinic acid & $\mathrm{C}_{30} \mathrm{H}_{48} \mathrm{O}_{4}$ & 471.348 & & ESI & [108] & & \\
\hline Methoxyloleuropein & $\mathrm{C}_{26} \mathrm{H}_{34} \mathrm{O}_{14}$ & 569.188 & & ESI & {$[100,102,103,108]$} & & \\
\hline Methoxyloleuroside & $\mathrm{C}_{26} \mathrm{H}_{34} \mathrm{O}_{14}$ & 569.188 & & ESI & [108] & & \\
\hline Methyl oleacein & $\mathrm{C}_{18} \mathrm{H}_{22} \mathrm{O}_{6}$ & 333.134 & $317.139^{\mathrm{a}}$ & APCI, ESI & {$[106]^{5}$} & & \\
\hline Methyl oleuropein aglycone & $\mathrm{C}_{20} \mathrm{H}_{24} \mathrm{O}_{8}$ & 391.14 & 393.154 & APCI, ESI & {$[106]^{5}$} & & \\
\hline $\begin{array}{l}\text { Monohydrated oleacein } \\
\text { (geminal diol) }\end{array}$ & $\mathrm{C}_{17} \mathrm{H}_{22} \mathrm{O}_{7}$ & 337.129 & & MALDI & & & {$[76]^{1}$} \\
\hline Monohydrated-EDA & $\mathrm{C}_{9} \mathrm{H}_{14} \mathrm{O}_{5}$ & 201.077 & & MALDI & & & {$[76]^{1}$} \\
\hline
\end{tabular}


Table 2. Cont.

\begin{tabular}{|c|c|c|c|c|c|c|c|}
\hline Name & Formula (M) & $\begin{array}{c}m / z \\
{[\mathrm{M}-\mathrm{H}]^{-}}\end{array}$ & $\begin{array}{c}m / z \\
{[\mathbf{M}+\mathbf{H}]^{+}}\end{array}$ & $\begin{array}{l}\text { Ionization } \\
\text { Source }\end{array}$ & Leaves & Olive Pomace & OOMW \\
\hline Naringenin & $\mathrm{C}_{15} \mathrm{H}_{12} \mathrm{O}_{5}$ & 271.089 & 273.076 & APCI, ESI & {$[106]^{5}$} & [132] & \\
\hline Neo-nüzhenide & $\mathrm{C}_{31} \mathrm{H}_{42} \mathrm{O}_{18}$ & 701.23 & & ESI, MALDI & {$[76]^{1}[108]$} & [128] & \\
\hline Nüzhenide & $\mathrm{C}_{31} \mathrm{H}_{42} \mathrm{O}_{17}$ & 685.235 & 687.25 & APCI, ESI & {$[99,103][106]^{5}$} & {$[49,133]$} & {$[133,134]$} \\
\hline Oleacin (3,4-DHPEA-EDA) & $\mathrm{C}_{17} \mathrm{H}_{20} \mathrm{O}_{6}$ & 319.119 & 321.133 & $\begin{array}{l}\text { APCI, ESI, } \\
\text { MALDI }\end{array}$ & {$[106]^{5}[108]$} & {$[127,131,133]$} & $\begin{array}{c}{[76]^{1}} \\
{[133,134]}\end{array}$ \\
\hline Oleanolic acid & $\mathrm{C}_{30} \mathrm{H}_{48} \mathrm{O}_{3}$ & 455.353 & & ESI & [108] & & \\
\hline Olenoside A and B & $\mathrm{C}_{11} \mathrm{H}_{14} \mathrm{O}_{5}$ & & $249.074^{c}$ & MALDI & & & {$[140]^{1}$} \\
\hline Oleocanthal ( $p$-HPEA-EDA) & $\mathrm{C}_{17} \mathrm{H}_{20} \mathrm{O}_{5}$ & 303.124 & 305.138 & APCI, ESI & {$[106]^{5}$} & {$[127,131,133]$} & {$[133,134]$} \\
\hline Oleoside & $\mathrm{C}_{16} \mathrm{H}_{22} \mathrm{O}_{11}$ & 389.109 & 391.117 & APCI, ESI & $\begin{array}{c}{[7,23,94,99,101-103]} \\
{[106]^{5}[108]}\end{array}$ & $\begin{array}{c}{[49,50,127,130} \\
132,133]\end{array}$ & $\begin{array}{c}{[133,134,} \\
136]\end{array}$ \\
\hline Oleoside diglucoside & $\mathrm{C}_{28} \mathrm{H}_{42} \mathrm{O}_{21}$ & 713.215 & & ESI & & {$[50,127]$} & \\
\hline Oleoside deoxyriboside & $\mathrm{C}_{20} \mathrm{H}_{26} \mathrm{O}_{15}$ & 505.12 & & ESI & & {$[49,50,127]$} & \\
\hline Oleoside dimethyl ester & $\mathrm{C}_{18} \mathrm{H}_{26} \mathrm{O}_{11}$ & 417.14 & & ESI & & [127] & \\
\hline $\begin{array}{c}\text { Oleoside glucoside } \\
\left(6^{\prime}-\beta \text {-glucopyranosyl-oleoside) }\right.\end{array}$ & $\mathrm{C}_{22} \mathrm{H}_{32} \mathrm{O}_{16}$ & 551.162 & & ESI & & {$[127,130]$} & \\
\hline $\begin{array}{l}\text { Oleoside methyl ester } \\
\text { derivative }\end{array}$ & $\mathrm{C}_{18} \mathrm{H}_{30} \mathrm{O}_{11}$ & 421.172 & & ESI & [7] & & \\
\hline $\begin{array}{l}\text { Oleuricine A (oleuropein } \\
\text { glucoside) }\end{array}$ & $\mathrm{C}_{31} \mathrm{H}_{42} \mathrm{O}_{18}$ & 701.23 & & MALDI & {$[76]^{1}$} & & \\
\hline $\begin{array}{l}\text { Oleuricine B (oleuroside } \\
\text { glucoside) }\end{array}$ & $\mathrm{C}_{31} \mathrm{H}_{42} \mathrm{O}_{18}$ & 701.23 & & MALDI & {$[76]^{1}$} & & \\
\hline Oleuropein & $\mathrm{C}_{25} \mathrm{H}_{32} \mathrm{O}_{13}$ & 539.177 & $\begin{array}{c}541.193 \\
558.218^{\mathrm{b}} \\
523.176^{\mathrm{a}}\end{array}$ & $\begin{array}{l}\text { APCI, ESI, FAB, } \\
\text { MALDI }\end{array}$ & $\begin{array}{c}{[7,23][76]^{1}[92]^{2}} \\
{[93]^{4}[94,97-103]} \\
{[106]^{5}[108,109]}\end{array}$ & $\begin{array}{c}{[96,127,128,130-} \\
133]\end{array}$ & $\begin{array}{c}{[133,134,} \\
136]\end{array}$ \\
\hline $\begin{array}{l}\text { Oleuropein aglycone } \\
\text { (3,4-DHPEA-EA) }\end{array}$ & $\mathrm{C}_{19} \mathrm{H}_{22} \mathrm{O}_{8}$ & 377.124 & 379.139 & $\begin{array}{l}\text { APCI, ESI, FAB, } \\
\text { MALDI }\end{array}$ & $\begin{array}{c}{[23][76]^{1}[92]^{2}} \\
{[94,99,102][106]^{5}} \\
{[108]}\end{array}$ & {$[49,127,131,133]$} & $\begin{array}{c}{[76]^{1}} \\
{[133,134]}\end{array}$ \\
\hline $\begin{array}{c}\text { Oleuropein aglycone } \\
\text { derivative }\end{array}$ & $\mathrm{C}_{19} \mathrm{H}_{20} \mathrm{O}_{7}$ & 359.117 & & ESI & & [128] & \\
\hline $\begin{array}{c}\text { Oleuropein aglycone } \\
\text { derivative }\end{array}$ & $\mathrm{C}_{16} \mathrm{H}_{26} \mathrm{O}_{10}$ & 377.145 & & ESI & {$[7,100,103]$} & [130] & {$[134,136]$} \\
\hline Oleuropein derivative & $\mathrm{C}_{25} \mathrm{H}_{36} \mathrm{O}_{12}$ & 527.213 & & ESI & & [127] & \\
\hline Oleuropein dimer & $\mathrm{C}_{50} \mathrm{H}_{62} \mathrm{O}_{25}$ & 1075.33 & & ESI & & [130] & \\
\hline Oleuropein glucoside isomers & $\mathrm{C}_{31} \mathrm{H}_{42} \mathrm{O}_{18}$ & 701.23 & $\begin{array}{c}703.244 \\
720.271^{\mathrm{b}}\end{array}$ & APCI, ESI, FAB & $\begin{array}{c}{[7][93]^{4}} \\
{[94,99-103][106]^{5}} \\
{[108]}\end{array}$ & {$[49,130,133]$} & {$[133,134]$} \\
\hline Oleuropein trimer & $\mathrm{C}_{75} \mathrm{H}_{90} \mathrm{O}_{39}$ & 1613.499 & & ESI & & [130] & \\
\hline Oleuroside & $\mathrm{C}_{25} \mathrm{H}_{32} \mathrm{O}_{13}$ & 539.177 & 541.193 & ESI & $\begin{array}{c}{[94,98,99,101-} \\
103,108]\end{array}$ & [49] & [134] \\
\hline Oxidized isoverbascoside & $\mathrm{C}_{29} \mathrm{H}_{34} \mathrm{O}_{15}$ & 621.183 & & ESI & & & [135] \\
\hline Oxidized verbascoside & $\mathrm{C}_{29} \mathrm{H}_{34} \mathrm{O}_{15}$ & 621.183 & & ESI & & & [135] \\
\hline$p$-Coumaric acid & $\mathrm{C}_{9} \mathrm{H}_{8} \mathrm{O}_{3}$ & 163.04 & 165.055 & APCI, ESI & {$[101,105][106]^{5}$} & {$[49,127,131,133]$} & {$[133,136]$} \\
\hline$p$-Coumaroyl aldarate & $\mathrm{C}_{15} \mathrm{H}_{16} \mathrm{O}_{10}$ & 355.067 & & ESI & & [49] & \\
\hline$p$-Coumaroyl hexoside & $\mathrm{C}_{15} \mathrm{H}_{18} \mathrm{O}_{8}$ & 325.093 & & ESI & & [49] & \\
\hline Phenylalanine & $\mathrm{C}_{9} \mathrm{H}_{11} \mathrm{NO}_{2}$ & 164.072 & & ESI & & [127] & \\
\hline $\begin{array}{l}p \text {-Hydroxybenzoic acid } \\
\text { (4-hydroxybenzoic acid) }\end{array}$ & $\mathrm{C}_{7} \mathrm{H}_{6} \mathrm{O}_{3}$ & 137.024 & 139.038 & APCI, ESI & {$[101,103][106]^{5}$} & & [138] \\
\hline Peonidin-3-O-rutinoside & $\mathrm{C}_{28} \mathrm{H}_{33} \mathrm{O}_{15}{ }^{+}$ & & 609.181 & ESI & [95] & & \\
\hline Pinoresinol & $\mathrm{C}_{20} \mathrm{H}_{22} \mathrm{O}_{6}$ & 357.134 & 359.149 & APCI, ESI & $\begin{array}{c}{[100,105][106]^{5}} \\
{[109]}\end{array}$ & {$[50,127,131,132]$} & \\
\hline Protocatechuic acid & $\mathrm{C}_{7} \mathrm{H}_{6} \mathrm{O}_{4}$ & 153.019 & 155.034 & APCI, ESI & {$[105][106]^{5}$} & [127] & [138] \\
\hline Quercetin & $\mathrm{C}_{15} \mathrm{H}_{10} \mathrm{O}_{7}$ & 301.035 & 303.05 & APCI, ESI & $\begin{array}{c}{[98,99,103,105]} \\
{[106]^{5}[108,109]}\end{array}$ & [127] & [134] \\
\hline Quercetin arabinose & $\mathrm{C}_{20} \mathrm{H}_{18} \mathrm{O}_{11}$ & 433.078 & & ESI & & [128] & \\
\hline Quercetin-4-O-glucoside & $\mathrm{C}_{21} \mathrm{H}_{20} \mathrm{O}_{12}$ & 463.088 & 465.101 & APCI, ESI & {$[106]^{5}[108]$} & & \\
\hline Quercetin-3-O-rhamnoside & $\mathrm{C}_{21} \mathrm{H}_{20} \mathrm{O}_{11}$ & 447.093 & 449.108 & ESI, MALDI & {$[76]^{1}$} & & [134] \\
\hline Quinic acid & $\mathrm{C}_{7} \mathrm{H}_{12} \mathrm{O}_{6}$ & 191.056 & 193.071 & APCI, ESI & {$[7,100,101][106]^{5}$} & {$[49,132]$} & [136] \\
\hline
\end{tabular}


Table 2. Cont

\begin{tabular}{|c|c|c|c|c|c|c|c|}
\hline Name & Formula (M) & $\begin{array}{c}m / z \\
{[\mathrm{M}-\mathrm{H}]^{-}}\end{array}$ & $\begin{array}{c}m / z \\
{[\mathbf{M}+\mathbf{H}]^{+}}\end{array}$ & $\begin{array}{l}\text { Ionization } \\
\text { Source }\end{array}$ & Leaves & Olive Pomace & OOMW \\
\hline $\begin{array}{l}\text { Quinone oxydized } \\
\text { hydroxytirosol }\end{array}$ & $\mathrm{C}_{8} \mathrm{H}_{8} \mathrm{O}_{3}$ & 151.04 & 153.054 & ESI & & [132] & \\
\hline Rutin & $\mathrm{C}_{27} \mathrm{H}_{30} \mathrm{O}_{16}$ & 609.146 & 611.161 & APCI, ESI & $\begin{array}{c}{[7][9]^{3}} \\
{[23,94,99-102]} \\
{[106]^{5}[108]}\end{array}$ & {$[127,130,131,133]$} & $\begin{array}{c}{[133,134} \\
136]\end{array}$ \\
\hline Secologanic acid & $\mathrm{C}_{18} \mathrm{H}_{26} \mathrm{O}_{10}$ & 401.145 & & ESI & & [127] & \\
\hline Secologanin & $\mathrm{C}_{17} \mathrm{H}_{24} \mathrm{O}_{10}$ & 387.13 & & ESI & & [127] & \\
\hline $\begin{array}{l}\text { Secologanoside (oleoside } \\
\text { positional isomer) }\end{array}$ & $\mathrm{C}_{16} \mathrm{H}_{23} \mathrm{O}_{11}$ & 389.109 & & APCI, ESI & $\begin{array}{c}{[7,23][76]^{1}} \\
{[99-103][106]^{5}} \\
{[108]}\end{array}$ & {$[127,132,133]$} & [133] \\
\hline Shikimic acid & $\mathrm{C}_{7} \mathrm{H}_{10} \mathrm{O}_{5}$ & 173.05 & & APCI, ESI & & [127] & \\
\hline Syringaresinol & $\mathrm{C}_{22} \mathrm{H}_{25} \mathrm{O}_{8}$ & 417.156 & 419.169 & APCI, ESI & {$[99,100][106]^{5}$} & & \\
\hline Taxifolin & $\mathrm{C}_{15} \mathrm{H}_{12} \mathrm{O}_{7}$ & 303.051 & 305.066 & APCI, ESI & $\begin{array}{c}{[7,99,100,103} \\
105][106]^{5} \\
\end{array}$ & [127] & \\
\hline Tyrosol & $\mathrm{C}_{8} \mathrm{H}_{10} \mathrm{O}_{2}$ & 137.061 & $121.064^{\mathrm{a}}$ & APCI, ESI & [23] [106] ${ }^{5}$ [109] & $\begin{array}{c}{[49,50,127,131,} \\
133]\end{array}$ & $\begin{array}{l}{[133,136,} \\
138,139]\end{array}$ \\
\hline Tyrosol glucoside & $\mathrm{C}_{14} \mathrm{H}_{20} \mathrm{O}_{7}$ & 299.114 & 301.13 & APCI, ESI & {$[102][106]^{5}$} & {$[127,133]$} & {$[133,134]$} \\
\hline Vanillic acid & $\mathrm{C}_{8} \mathrm{H}_{8} \mathrm{O}_{4}$ & 167.035 & & ESI & [105] & {$[127,131-133]$} & {$[133,138]$} \\
\hline Vanillic acid hexoside & $\mathrm{C}_{14} \mathrm{H}_{18} \mathrm{O}_{9}$ & 329.088 & & ESI & & {$[49]$} & \\
\hline Vanillin & $\mathrm{C}_{8} \mathrm{H}_{8} \mathrm{O}_{3}$ & 151.04 & & ESI & $\begin{array}{c}{[7,100,101,103,} \\
109]\end{array}$ & [131] & \\
\hline Verbascoside & $\mathrm{C}_{29} \mathrm{H}_{36} \mathrm{O}_{15}$ & 623.198 & 625.213 & APCI, ESI & $\begin{array}{c}{[7,23,94,98,101} \\
102,105][106]^{5} \\
{[108]} \\
\end{array}$ & $\begin{array}{c}{[49,96,127,128,} \\
130,131,133]\end{array}$ & [133-136] \\
\hline
\end{tabular}

Although the classical Folin-Ciocalteu method is often applied to assess the total content of phenolic compounds also in plant-related extracts [141], analytical approaches enabling the characterization of specific compounds are clearly required to assess the possibility to recover valuable components [142]. In this context, RP, hydrophilic interaction liquid chromatography (HILIC) and supercritical fluid chromatography (SFC) have been employed as analytical separating means of phenolic compounds in OP [49]. While the use of UV-Vis DAD or fluorescence detectors (FD) has been reported [50], ESI-MS and, recently, MALDI-MS [76], are most useful to provide detailed structural characterization. As an example, ultra-high performance liquid chromatography (UHPLC) and high resolution MS led to overcome the problems due to the co-elution of HT-4- $\beta$-D-glucoside and HT occurring in the olive pulp, OMWW, and OP extracts [143]. The existence of flavonol glucosides, anthocyanins and derivatives of hydroxycinnamic acids in olive oil processing wastes can be easily predicted, since such compounds were reported to be present in olive drupes already in studies dating back to two decades ago [144,145]. Cardoso et al. [130,146] compared the methanol extract of olive pulp and OP and collected 27 fractions that were further investigated by ESI-MS. As a result, some common phenolic compounds, many of which found also in olive leaves, namely, verbascoside, rutin, caffeoyl-quinic acid, luteolin4-glucoside, 11-methyl-oleoside, HT-1'- $\beta$-glucoside, luteolin-7-O-rutinoside, oleoside (with two derivatives, 6 - $\beta$-glucopyranosyl-oleoside and $6^{\prime}-\beta$-rhamnopyranosyl-oleoside), and 10-hydroxy-oleuropein were found. An oleuropein glucoside previously detected in olive leaves was also found in both matrices. In quantitative terms, most of the phenolic compounds were found in equivalent amounts in olive pulp and pomace, except oleoside, which was the main phenolic compound in olive pulp $(31.6 \mathrm{mg} / \mathrm{g})$ but was tenfold lowered in OP, and oleuropein, almost absent in OP (2.7 mg/g in the pulp). Cioffi et al. [147] used HPLC-DAD analysis to assess the phenolics content in virgin olive oils and OP of samples collected in the area of Cilento (Campania, Southern Italy). In all the investigated samples, secoiridoids represented about $50-70 \%$ of the total phenolic compounds with oleuropein and ligstroside aglycone being the most abundant ones, although oleocanthal (see Figure 2) was also identified and quantified. Among simple phenols, gallic acid, HT, and tyrosol were 
the major constituents in olive oil, while caffeic acid, tyrosol, and gallic acid prevailed in OP (see Table 3). Moreover, leaves and olive extracts were found to elicit a strong free-radical scavenging activity, assessed using the 2,2-diphenyl-1-picryl-hydrazyl-hydrate (DPPH) test and correlated to the high total content of phenols, while the OP extract showed a lower antioxidant activity. In another study [148], the concentration of oleocanthal was evaluated both in OP and freshly pressed extra-virgin olive oils (EVOO) obtained after early, mid and late season harvests. While similar levels of oleocanthal were found in pomace and in EVOO from early and mid harvests, the EVOO obtained after late harvest showed greater contents compared to pomace, likely due to chemical and enzymatic degradation of olive drupes with maturation. These findings suggested that pomace waste from early and mid harvests might represent a precious source of oleocanthal. LozanoSanchez et al. [149] characterized phenolic compounds and polar molecules occurring in both solid and aqueous wastes arising from olive oil production by LC coupled to ESITOF-MS and IT-MS. Phenolic compounds such as vanillin, HT, tyrosol, luteolin, apigenin and quinic acid (see Figure 3 and Table 3) were quantitated using external calibrations of commercial standards. When no commercial standard was available, the quantitation was accomplished by compounds with similar chemical structures. Therefore, secoiridoids and lignans were respectively quantified using oleuropein and (+)-pinoresinol standards. The main components of phenolic fraction in solid wastes were found to be the dialdehydic form of decarboxymethyl-elenolic acid (see Figure 2) and HT, with concentrations ranging from 153 to $601 \mathrm{mg} / \mathrm{kg}$ and from 159 to $181 \mathrm{mg} / \mathrm{kg}$, respectively. Among secoiridoids, oleuropein aglycone and its hydroxylated and decarboxymethylated derivatives were the most abundant compounds. The same authors proposed the occurrence of novel oxidized and hydrated compounds related to elenolic acid.

Table 3. Range of concentrations of bioactive compounds reported in leaves ( $\mathrm{mg} / \mathrm{g})$, olive pomace ( $\mathrm{mg} / \mathrm{kg})$ and in olive oil mill wastewaters (mg/kg) (OOMW).

\begin{tabular}{|c|c|c|c|c|c|c|}
\hline Name & Leaves & Refs. & OP & Refs. & OOMW & Refs. \\
\hline 3,4- dihydroxyphenylglycol & & & $7.50-20.16$ & [150] & & \\
\hline $\begin{array}{l}\text { Oleoside glucoside }\left(6^{\prime}-\beta-\right. \\
\text { glucopyranosyl-oleoside) }\end{array}$ & & & $5.0-5.0$ & {$[130]^{b}$} & & \\
\hline $6^{\prime}$ - $\beta$-rhamnopyranosyl-oleoside & & & $6.4-6.6$ & {$[130]^{b}$} & & \\
\hline Acteoside & $7.8-9.2$ & [103] & & & & \\
\hline Acetoxypinoresinol & & & $\begin{array}{l}9.32-12.2 \\
14.4-15.2\end{array}$ & $\begin{array}{l}{[149]} \\
{[132]}\end{array}$ & & \\
\hline Apigenin & $0.06-0.12$ & [105] & $\begin{array}{c}0.195-0.501 \\
11.4-13.6 \\
19.5-25.5 \\
29.7-29.9\end{array}$ & $\begin{array}{c}{[149]} \\
{[151]} \\
{[96]} \\
{[132]}\end{array}$ & $2.5-6.5$ & [151] \\
\hline Apigenin-7-O-glucoside & $\begin{array}{c}0.197-0.217 \\
0.230-0.386 \\
0.33-0.36\end{array}$ & $\begin{array}{l}{[96]} \\
{[102]} \\
{[105]}\end{array}$ & $5.3-7.1$ & [96] & & \\
\hline Apigenin-7-O-rutinoside & & & $0.7-0.9$ & [151] & & \\
\hline Caffeic acid & $\begin{array}{c}0.012-0.018 \\
0.60-0.66 \\
1.0-1.2\end{array}$ & $\begin{array}{c}{[105]} \\
{[103]} \\
{[34]}\end{array}$ & $\begin{array}{l}6.7-13.5 \\
67-69\end{array}$ & $\begin{array}{l}{[147]} \\
{[49]^{a}}\end{array}$ & $\begin{array}{c}19.2-57.3 \\
0.014-0.017\end{array}$ & $\begin{array}{l}{[151]} \\
{[5]^{d}}\end{array}$ \\
\hline Chlorogenic acid (Caffeoyl-quinic acid) & $0.00187-0.00347$ & [105] & & & & \\
\hline Chrysoeriol-7-O-glucoside & $0.581-0.845$ & [102] & & & & \\
\hline Demethyloleuropein & $1.338-6.382$ & {$[102]$} & $11.2-22.4$ & [151] & & \\
\hline Elenolic acid (EA) & & & $2.1-2.6$ & [151] & $4.9-11.7$ & [151] \\
\hline $\begin{array}{l}\text { Elenolic acid (EA) derivative } \\
\text { (decarboxylated form of } \\
\text { hydroxyelenolic acid) }\end{array}$ & & & $\begin{array}{c}59-61 \\
153-601\end{array}$ & $\begin{array}{l}{[132]} \\
{[149]}\end{array}$ & & \\
\hline Elenolic acid (EA) derivative & & & $788-896$ & [150] & & \\
\hline Elenolic acid decarboxymethylated (EDA) & & & $515-601$ & [150] & & \\
\hline
\end{tabular}


Table 3. Cont.

\begin{tabular}{|c|c|c|c|c|c|c|}
\hline Name & Leaves & Refs. & OP & Refs. & OOMW & Refs. \\
\hline $\begin{array}{l}\text { Elenolic acid glucoside } \\
\text { (Oleoside methyl ester) }\end{array}$ & $0.267-1.367$ & [102] & 32.9-33.9 & [132] & & \\
\hline Eriodictyol & $0.0062-0.0074$ & [105] & & & & \\
\hline Ferulic acid & $\begin{array}{l}0.035-0.055 \\
15-37\end{array}$ & $\begin{array}{c}{[105]} \\
{[34]}\end{array}$ & 12.6 & [147] & & \\
\hline Gallic acid & $\begin{array}{c}0.0020-0.0032 \\
0.3-1.8 \\
\end{array}$ & $\begin{array}{c}{[105]} \\
{[34]}\end{array}$ & $\begin{array}{c}0.0-1.6 \\
11.4-12.6 \\
\end{array}$ & $\begin{array}{l}{[151]} \\
{[147]} \\
\end{array}$ & $\begin{array}{l}3.86-6.71 \\
22.2-61.0 \\
\end{array}$ & $\begin{array}{l}{[138]} \\
{[151]}\end{array}$ \\
\hline Hydro-oleuropein & & & 99-101 & [132] & & \\
\hline Hydroxytyrosol (3,4-DHPEA) & $\begin{array}{c}6-24 \\
18.3-20.1\end{array}$ & $\begin{array}{l}{[34]} \\
{[97]}\end{array}$ & $\begin{array}{c}8.4-10.4 \\
60-163 \\
159-181 \\
799-1059 \\
809-853\end{array}$ & $\begin{array}{c}{[147]} \\
{[58]} \\
{[149]} \\
{[150]} \\
{[96]}\end{array}$ & $\begin{array}{c}157.2-245.1 \\
483.0-1733.2 \\
544-1560 \\
1230-1290 \\
0.25-18.2 \\
0.0020-0.1224\end{array}$ & $\begin{array}{c}{[151]} \\
{[138]} \\
{[80]^{-}} \\
{[77]{ }^{\mathrm{c}}} \\
{[139]^{\mathrm{c}}} \\
{\left[^{\mathrm{d}}\right]^{\mathrm{d}}}\end{array}$ \\
\hline Hydroxytyrosol acetate & $16.6-18.8$ & [97] & $\begin{array}{c}44-167 \\
562-866\end{array}$ & $\begin{array}{l}{[58]} \\
{[150]}\end{array}$ & & \\
\hline Hydroxytyrosol diglucoside & & & $87.0-89.6$ & {$[49]^{\mathrm{a}}$} & & \\
\hline Hydroxytyrosol glucoside & $0.340-0.793$ & [102] & $\begin{array}{c}164.0-166.4 \\
6.2-6.8\end{array}$ & $\begin{array}{l}{[49]^{\mathrm{a}}} \\
{[130]^{\mathrm{b}}}\end{array}$ & $1300-1700$ & {$[77]$} \\
\hline Ligstroside & $3.251-3.845$ & [102] & $\begin{array}{c}2.5-2.9 \\
15.7-17.3 \\
\end{array}$ & $\begin{array}{l}{[151]} \\
{[132]} \\
\end{array}$ & $0.0087-0.0092$ & {$[5]^{\mathrm{d}}$} \\
\hline Luteolin & $\begin{array}{c}0.216-0.224 \\
0.367-0.497 \\
1.16-1.30 \\
10.4-53.5\end{array}$ & $\begin{array}{c}{[105]} \\
{[102]} \\
{[103]} \\
{[97]} \\
\end{array}$ & $\begin{array}{c}11.3-147.3 \\
14.3-32.7 \\
19.3-25.5 \\
217-225 \\
\end{array}$ & $\begin{array}{c}{[149]} \\
{[151]} \\
{[96]} \\
{[132]} \\
\end{array}$ & $\begin{array}{c}2.5-36.2 \\
270-510 \\
0.0145-0.021\end{array}$ & $\begin{array}{c}{[151]} \\
{[77]} \\
{[5]^{\mathrm{d}}}\end{array}$ \\
\hline Luteolin diglucoside & $0.201-0.364$ & [102] & $3.2-3.2$ & [151] & & \\
\hline Luteolin-4'-O-glucoside & $70.1-71.1$ & [97] & $0.46-0.48$ & {$[130]^{\mathrm{b}}$} & & \\
\hline Luteolin-7-O-glucoside & $\begin{array}{c}0.145-0.165 \\
2.16-2.34 \\
5.6-6.6 \\
68-90 \\
\end{array}$ & $\begin{array}{c}{[96]} \\
{[105]} \\
{[45]} \\
{[97]} \\
\end{array}$ & $\begin{array}{l}12.0-16.6 \\
19-23 \\
2.1-2.1\end{array}$ & $\begin{array}{c}{[96]} \\
{[132]} \\
{[130]^{b}}\end{array}$ & $0-0.0214$ & {$[5]^{\mathrm{d}}$} \\
\hline Luteolin-7-O-rutinoside & & & $\begin{array}{l}1.0-1.2 \\
2.2-2.4 \\
\end{array}$ & $\begin{array}{l}{[151]} \\
{[132]} \\
\end{array}$ & & \\
\hline Luteolin-hexoside & $1.072-1.744$ & [102] & & & $3.2-24.2$ & [151] \\
\hline Luteolin-O-rutinoside & $0.199-0.491$ & {$[102]$} & $0.31-0.34$ & {$[130]^{b}$} & & \\
\hline Methoxyloleuropein & $0.870-2.188$ & [102] & & & & \\
\hline Oleacin (3,4-DHPEA-EDA) & & & $2.5-3.0$ & [151] & $11300-45951$ & [80] \\
\hline Oleoside & $0.366-0.399$ & {$[102]$} & $3.4-3.7$ & {$[130]^{b}$} & & \\
\hline Oleuropein & $\begin{array}{c}0.13-21.34 \\
17.1-18.1 \\
18.2-19.9 \\
52-58 \\
60-90 \\
83-87 \\
92.5-345.3 \\
\end{array}$ & $\begin{array}{c}{[95]} \\
{[102]} \\
{[96]} \\
{[45]} \\
{[122]} \\
{[103]} \\
{[97]} \\
\end{array}$ & $\begin{array}{c}1.3-11.0 \\
7.62-14.67 \\
33-41 \\
81.7-83.0 \\
93-95\end{array}$ & $\begin{array}{l}{[151]} \\
{[150]} \\
{[96]} \\
{[147]} \\
{[132]}\end{array}$ & $\begin{array}{l}5.7-27.0 \\
420-560\end{array}$ & $\begin{array}{c}{[151]} \\
{[77]}\end{array}$ \\
\hline $\begin{array}{c}\text { Oleuropein aglycone } \\
(3,4 \text {-DHPEA-EA) }\end{array}$ & $0.134-0.288$ & [102] & $\begin{array}{l}23.3-24.0 \\
23.5-48.0\end{array}$ & $\begin{array}{l}{[147]} \\
{[149]}\end{array}$ & & \\
\hline Oleuropein aglycone derivative & & & $45.7-152.8$ & [149] & & \\
\hline Oleuropein derivative & $0.648-1.948$ & [34] & $27.6-39.2$ & [150] & $5400-7600$ & [77] \\
\hline Oleuroside & $2.100-2.337$ & [102] & $0.4-1.4$ & [151] & $200-400$ & [77] \\
\hline$p$-Coumaric acid & $\begin{array}{l}0.072-0.090 \\
0.9-5.6\end{array}$ & $\begin{array}{c}{[105]} \\
{[34]}\end{array}$ & $\begin{array}{c}0.8-0.9 \\
17.2-18.2 \\
\end{array}$ & $\begin{array}{l}{[151]} \\
{[49]^{a}} \\
\end{array}$ & $15.9-21.8$ & [151] \\
\hline $\begin{array}{l}\text { Ligstroside aglycone } \\
(p \text {-HPEA-EA })\end{array}$ & & & $\begin{array}{c}0.3-10.2 \\
27.1-31.1\end{array}$ & $\begin{array}{l}{[151]} \\
{[147]}\end{array}$ & & \\
\hline Oleocanthal ( $p$-HPEA-EDA) & & & $\begin{array}{c}1.9-2.3 \\
62.4-128.3 \\
\end{array}$ & $\begin{array}{l}{[151]} \\
{[148]}\end{array}$ & & \\
\hline $\begin{array}{l}p \text {-Hydroxybenzoic acid } \\
\text { (4-hydroxybenzoic acid) }\end{array}$ & $\begin{array}{c}0.0143-0.0163 \\
0.9-4.2 \\
\end{array}$ & $\begin{array}{c}{[105]} \\
{[34]}\end{array}$ & $6.86-13.80$ & [150] & $1.75-6.15$ & [138] \\
\hline Pinoresinol & $0.0033-0.0047$ & [105] & $\begin{array}{l}2.6-3.2 \\
17-137\end{array}$ & $\begin{array}{c}{[132]} \\
{[58]}\end{array}$ & & \\
\hline Protocatechuic acid & $\begin{array}{c}0.013-0.021 \\
32-37\end{array}$ & $\begin{array}{c}{[105]} \\
{[34]}\end{array}$ & $\begin{array}{c}1.3-3.8 \\
38.4-44.4\end{array}$ & $\begin{array}{l}{[151]} \\
{[150]}\end{array}$ & $\begin{array}{c}2.77-5.29 \\
25.3-136.7\end{array}$ & $\begin{array}{l}{[138]} \\
{[151]} \\
\end{array}$ \\
\hline Quercetin & $0.037-0.043$ & {$[105]$} & & & & \\
\hline Quinic acid & & & $\begin{array}{c}203-243 \\
529-1485 \\
\end{array}$ & $\begin{array}{l}{[132]} \\
{[149]} \\
\end{array}$ & & \\
\hline
\end{tabular}


Table 3. Cont

\begin{tabular}{|c|c|c|c|c|c|c|}
\hline Name & Leaves & Refs. & OP & Refs. & OOMW & Refs. \\
\hline Rutin & $0.289-0.651$ & [102] & $\begin{array}{c}0.63-0.69 \\
1.1-1.5 \\
\end{array}$ & {$\left[{ }^{[130]^{b}}{ }^{\mathrm{b}}\right.$} & $440-640$ & [77] \\
\hline $\begin{array}{c}\text { Secologanoside } \\
\text { (oleoside positional isomer) }\end{array}$ & $1.823-3.677$ & [102] & $34-46$ & [132] & & \\
\hline Taxifolin & $0.0070-0.0094$ & [105] & & & & \\
\hline Tyrosol & $3-14$ & [34] & $\begin{array}{c}20.7-21.6 \\
34-71 \\
69.6-196.7 \\
96-124\end{array}$ & $\begin{array}{c}{[147]} \\
{[58]} \\
{[150]} \\
{[149]}\end{array}$ & $\begin{array}{c}218.4-581.0 \\
1180-1560 \\
0.19-4.32 \\
0.0145-0.0208\end{array}$ & $\begin{array}{c}{[138]} \\
{[77]^{\mathrm{c}}} \\
{[139]^{\mathrm{c}}} \\
{[5]^{\mathrm{d}}}\end{array}$ \\
\hline Tyrosol glucoside & $0.863-1.278$ & [102] & $6.6-12.1$ & [151] & & \\
\hline Vanillic acid & $0.010-0.020$ & [105] & $\begin{array}{c}1.3-1.7 \\
8.8-10.4 \\
20.6-25.2\end{array}$ & $\begin{array}{l}{[151]} \\
{[147]} \\
{[150]}\end{array}$ & $\begin{array}{c}1.68-62.7 \\
0.0174-0.0198\end{array}$ & $\begin{array}{l}{[138]} \\
{[5]^{d}}\end{array}$ \\
\hline Vanillin & & & $140-150$ & [149] & & \\
\hline Verbascoside & $\begin{array}{c}1.127-4.069 \\
1.382-1.474 \\
1.71-2.09 \\
2.730-3.090\end{array}$ & $\begin{array}{c}{[102]} \\
{[96]} \\
{[45]} \\
{[105]}\end{array}$ & $\begin{array}{c}0.4-1.6 \\
17.6-23.0\end{array}$ & $\begin{array}{l}{[151]} \\
{[96]}\end{array}$ & $\begin{array}{c}14496-24100 \\
1620-1760 \\
0.0075-0.0155\end{array}$ & $\begin{array}{l}{[80]} \\
{[77]} \\
{[5]^{\mathrm{d}}}\end{array}$ \\
\hline
\end{tabular}

Content expressed as $\mathrm{mg} / \mathrm{L}^{\mathrm{a}}, \mathrm{mg} / \mathrm{g}^{\mathrm{b}}, \mathrm{mg} / \mathrm{mL}^{\mathrm{c}}$, and weight $\%{ }^{\mathrm{d}}$.

The selection of the extraction solvents must be carefully made not only considering the chemical and physical properties of the target substances while minimizing matrix interferences but also avoiding toxic, inflammable, and hazardous mixtures. Lunque de Castro and coworkers [127] reported a detailed investigation of phenolics and other polar compounds occurring in OP extracted by a superheated water/ethanol mixture 50:50 (v/v) at $160^{\circ} \mathrm{C}$. The identification was validated by accurate $m / z$ ratios and isotopic patterns of precursor ions and their related product ions. In a subsequent paper, minor secoiridoids and other phenolic compounds were identified in the alperujo extract, treated with polyamide and XAD resin, using ESI-FTMS [128]. The extract was concentrated and purified by solid phase extraction (SPE) using a RP C18 cartridge, collecting three main fractions enriched in minor compounds. The latter corresponded to several oleuropein derivatives, as oleoside methyl ester, dihydro-oleuropein, neo-nüzhenide (an analogue of nüzhenide including HT, instead of tyrosol) and oleuropein diglycoside, never identified before. A novel secoiridoid glucoside, i.e., 1- $\beta$-D-glucopyranosyl acyclodihydroelenolic acid, was recognised in alperujo for the first time also recurring to NMR [128]. Especially during the first decade of the new millennium, this last spectroscopic technique has played an important role in the identification of phenolic compounds in OP and OMWW, by analogy with olive leaves. As an example, the purity of 3,4-dihydroxyphenylglycol (DHPG), a compound corresponding to HT having an additional $\mathrm{OH}$ group on the ethyl chain, described as a strong antioxidant component of both OP and OMWW, was assessed by NMR [152]. In a subsequent paper, the precursors of DHPG were identified and characterized after extraction from alperujo; three compounds, all containing a DHPG moiety, were recognized as precursors, namely the diastereoisomeric forms of both $\beta$-hydroxy derivatives of verbascoside and isoverbascoside ( $\beta$-hydroxyacteoside and $\beta$-hydroxyisoacteoside), and 2"-hydroxyoleuropein [129].

By combining ${ }^{1} \mathrm{H}$ NMR, ${ }^{13} \mathrm{C}$ NMR, IR, UV and ESI-MS Rigane et al. [137] identified a new iridoid compound, deoxyloganic acid lauryl ester, in OP obtained from a two-phase decanter during the extraction of Chemlali olive oil; the antioxidant activity of the pure compound was assessed by in vitro tests. Damak et al. [140] reported the first isolation and characterization of Olenoside A and its known epimer Olenoside B, present in OMWW as an isomeric mixture. Their structures were determined by 2D NMR and confirmed, for the most abundant isomer, by X-ray diffraction. Further, 1D and 2D NMR spectroscopy was proved to be a useful tool for olive oil production wastes fingerprinting without separation and pre-treatment of samples. The chemical composition of major and minor components, like secoiridoids, lignans, and phenolic compounds present in chloroform extracts of olive paste and pomace was evaluated by this approach [153]. Rapid NMR fingerprinting can be used to determine the entire profile of phenolics in different waste materials generated 
by the olive oil production process, thus contributing to their valorisation. For example, Hafidi et al. studied the aerobic digestion of OMWW under various medium conditions to determine the best treatment of residue stabilisation; FTIR and ${ }^{13} \mathrm{C}$ NMR spectroscopies were used to compare results showing that treatment of OMWW by soil micro-flora with $\mathrm{pH}$ neutralization by phosphate could be considered the best one, allowing good stabilisation of organic matter and high preservation of nitrogen in the humic form [154]. More recently, the degradation of OMWW by different methods was studied by FTIR: results showed that treatment with $\mathrm{H}_{2} \mathrm{O}_{2}$ under high pressure and temperature removed $89.2 \%$ of COD, $91.5 \%$ of phenolic compounds, and the colour of OMWW; the comparison of NMR spectra confirmed that all phenolic compounds and the majority of other compounds were abated [155].

Turning back to phenolic compounds and their investigation by MS, a direct and fast analytical method based on UHPLC-DAD coupled with ESI/MS-MS was applied to OP by Malapert et al. [49]. In a short analysis time (ca. $12 \mathrm{~min}$ ), thirty-five metabolites belonging to the classes of phenyl alcohols, secoiridoids, flavonoids, and iridoids, including a novel $p$-coumaroyl aldarate, a verbascoside derivative and a new ligstroside derivative, were identified as the main constituents of alperujo. More recently, an extended overview of the distribution of bioactive compounds along the entire production chain, from drupes to oil and processing wastes was described by Russo et al. [151] by LC-MS.

As recently evidenced for olive oil secoiridoids, whose profile is affected by various parameters, including olive cultivar and geographical origin [156], ripening stage at the harvesting time, agronomic and technological practices $[157,158]$, and whose integrity was influenced by storage conditions [158], the distribution and integrity of phenolic compounds contained in OP and OOMW is expected to be affected as well. These differences are manifest when a comparison in quantitative terms is attempted (see Table 3). Among them, storage is particularly challenging since those by-products of olive oil production can be stored in ponds even for some months during the olive oil processing season. Brenes et al. [159] compared the phenolic content of refined oils as lamp oil, crude OP oil and second centrifugation olive oils at various storage times, observing an increase of HT, HT-acetate, tyrosol, catechol, flavonoids luteolin and apigenin and vanillic acid with storage time. HPLC-MS and GC-MS were employed to identify 4-ethylphenol, responsible for the unpleasant odour of "wet horse", which was also intensified with time storage. Medina et al. [60] studied the changes of phenols during both the storage phase in open air ponds and the extracting process. Considering the decrease of oleuropein and HT-glycoside concentrations from harvested olives to alperujo they concluded that most of this $o$-diphenolic species were lost mainly due to enzymatic oxidation during malaxation and further manipulation steps of the olive paste. The technique adopted for the extraction from $\mathrm{OP}$ can also create different qualitative and quantitative phenolic profiles. Using pressurized liquid extraction under optimized conditions, the total amount of secoiridoids and flavonoids was three- and four-times higher than that found in conventional extracts, as determined by HPLC-DAD-ESI-TOF/MS [132]. In a further study, supercritical carbon dioxide was used to extract oil from alperujo and the total phenol content was very high as assessed by HPLC-DAD, with the highest HT content $(1.9 \mathrm{~g} / \mathrm{kg})$ being recovered [160].

Even if a certain degree of variability exists, it can be resumed that the most abundant phenolic compounds in OP are HT (1.8\%), tyrosol, $p$-coumaric acid, oleuropein, vanillic acid, verbascoside, cinnamic acid, caffeic acid, elenolic acid, catechol, ferulic acid, gallic acid, syringic acid, sinapic acid, HT-10- $\beta$-glucoside, homovanillic acid, demethyloleuropein, ligstroside, 11-methyloleoside. Among flavonoids, luteolin, luteolin 7-O-glucoside, luteolin4-O-glucoside, luteolin-7-O-rutinoside, rutin, hesperidin, quercetin, apigenin, apigenin 7-O-glucoside, cyanidin 3-O-rutinoside, and cyanidin 3-O-glucoside can be considered the most relevant $[120,161]$ (See Tables 2 and 3). Since the amount of several of these compounds in OP can often exceed that found in olive oils, their recovery may represent a convenient strategy for their use in the food, cosmetic and pharmaceutical industries. 
However, as highlighted from quantitative data, the retrieved amount largely depends on several factors which makes necessary a standardization of the phenolic extraction.

OMWW is an important by-product of olive oil production in which a relevant fraction of hydrophilic bioactive compounds is expected to be transferred into it. One of the first LCESI-MS /MS method of tyrosol and HT quantification in OMWW was proposed by Bazoti et al. in 2006 [139]. Specific transitions were observed in negative ion mode, i.e., $137 \rightarrow 119$ for tyrosol, $153 \rightarrow 123$ for HT and $201 \rightarrow 125$ due to 2-(5-ethylidene-2-oxo-tetrahydro-2Hpyran-4-yl) acetic acid, which is generated by cleavage of oleuropein aglycone. Good linearity, precision, and accuracy was demonstrated because of baseline resolution of chromatographic peaks, combined with the MS selectivity of multiple reaction monitoring.

The profile of elenolic acid derivatives in OMWW was very recently proposed by Mattonai et al. [138] using a LC column with embedded polar groups. HT and tyrosol were found as main components (see Table 3) and an important depletion in the phenolic content of OMWW after one year of storage was proved. Moreover, unknown components, such as HT-esters of elenolic acid were identified and their presence was evidenced as a marker for evaluating the OMWW ageing. UPLC-ESI-MS/MS was used by Suàrez et al. [131] with the aim of preparing phenolic extracts from olive cake for potential application as food antioxidants; a complete list of phenolic compounds obtained from the solid and the liquid fraction of olive cake was reported. An interesting demonstration of the high variability of OMWW composition is represented by the study of Cardoso et al. [162], who found seven new bioactive phenols in two Portuguese OMWW using ESI-MS and MS ${ }^{\mathrm{n}}$ analyses. Oleuropein and ligstroside isomers including the glucose unit linked to a phenolic $\mathrm{OH}$ group were discovered. Moreover, ions detected at nominal $\mathrm{m} / z$ ratios 863, 685 and 847 were respectively assigned to glucosidic derivatives of the oleuropein isomer and a monoand di-glucosides of the ligstroside isomer, thus showing that even secoiridoids with a relatively high molecular weight can be found in OMWW. Similarly, verbascoside, isoverbascoside and their derivatives were characterized and quantified via LC-DAD-MS/MS analysis by Cardinali et al. [135] employing low-pressure gel filtration chromatography. The potentiality of RPLC-ESI-DAD-MS for olive mill waste characterization was confirmed by Obied et al. [134], that demonstrated the presence of 52 compounds in OMW; with a similar approach, 23 compounds, belonging to secoiridoids and their derivatives, phenyl alcohols, phenolic acid and derivatives, and flavonoids, were identified in OMWW coming from Italian and Greek olive cultivars by D'Antuono et al. [136]. In quantitative terms, OMWW seems a very promising source of valuable compounds as oleacin, tyrosol, HT, verbascoside, HT glucoside, caffeic acid, gallic acid, luteolin, oleoside, oleuropein and derivative, oleuroside and rutin (see Table 3).

Among MS-based techniques applied to the characterization of phenolic compounds in olive oil production by-products, specific considerations are deserved by MS relying on matrix assisted laser desorption ionization (MALDI). Despite the well-known advantages of MALDI, such as rapidity, sensitivity, easy sample preparation, MALDI-ToF/ToF MS has rarely been applied to the analysis of secoiridoids and closely related by-products. This task has been recently accomplished in our laboratory by using binary matrices such as 1,8-bis(dimethylamino) naphthalene/9-aminoacridine (DMAN/9AA) [163] or 1,8bis(tetramethylguanidino)naphthalene/9-aminoacridine (TGMN/9AA) in negative ion mode [76]. As a result, HT and decarboxymethyl-elenolic acid were identified as major component; secoiridoids oleuropein aglycone and oleacein were detected in the MALDI-MS spectrum of OMWW as well. Moreover, the identification of 3,4-dihydroxyphenyglycol, the geminal diol of oleacein and an hydroxylated derivative of decarboxymethyl-elenolic acid was tentatively made [76]. The same approach was also applied to olive leaves extracts and oleuropein was confirmed as the major phenolic compound. Luteoline, oleoside, secologanoside (see Figure 2) and isomeric oleuropein diglucosides were also identified. 


\section{Conclusions}

The application of increasingly advanced mass spectrometry techniques over almost three decades, boosted by the introduction of soft ionization sources and, recently, also MALDI, has led to a remarkable amount of information on potentially bioactive compounds, mainly belonging to the classes of phenolics and secoiridoids, in typical by-products of olive oil production, namely olive leaves, olive pomace and olive oil mill wastewater. Liquid chromatography has certainly played a key role, enabling the preliminary separation of several compounds in such a complex type of matrices. With the increasing awareness of the potential of these by-products as sources of valuable compounds, useful for different types of industries (food, cosmetics, etc.), the role of mass spectrometry in estimating which of them is more promising in the perspective of recovering a specific compound is expected to become progressively more relevant in the next future.

Author Contributions: Conceptualization, R.A., G.V., C.D.C., I.L.; writing—original draft preparation, R.A., G.V.; writing-review and editing, C.D.C., T.R.I.C., I.L.; supervision, C.D.C., I.L.; funding acquisition, T.R.I.C., I.L. All authors have read and agreed to the published version of the manuscript.

Funding: This research was funded by Fondazioni in Rete per la Ricerca Agroalimentare (AGER), Grant Number AGER 2016-0169 ("VIOLIN" project) and "The APC was funded by MDPI-Foods".

Institutional Review Board Statement: Not applicable.

Informed Consent Statement: Not applicable.

Data Availability Statement: Not applicable.

Acknowledgments: We thank the Italian Ministero per l'Istruzione, l'Università e la Ricerca (MIUR), Grant Number PONa3_00395/1 for the support.

Conflicts of Interest: The authors declare no conflict of interest.

\section{References}

1. Roig, A.; Cayuela, M.L.; Sánchez-Monedero, M.A. An overview on olive mill wastes and their valorisation methods. Waste Manag. 2006, 26, 960-969. [CrossRef]

2. Alburquerque, J.A.; Gonzálvez, J.; García, D.; Cegarra, J. Agrochemical characterisation of "alperujo", a solid by-product of the two-phase centrifugation method for olive oil extraction. Bioresour. Technol. 2004, 91, 195-200. [CrossRef]

3. Gogebakan, Z.; Gogebakan, Y.; Selçuk, N.; Selçuk, E. Investigation of ash deposition in a pilot-scale fluidized bed combustor co-firing biomass with lignite. Bioresour. Technol. 2009, 100, 1033-1036. [CrossRef] [PubMed]

4. $\quad$ Bhatnagar, A.; Kaczala, F.; Hogland, W.; Marques, M.; Paraskeva, C.A.; Papadakis, V.G.; Sillanpää, M. Valorization of solid waste products from olive oil industry as potential adsorbents for water pollution control-a review. Environ. Sci. Pollut. Res. 2014, 21, 268-298. [CrossRef] [PubMed]

5. Dermeche, S.; Nadour, M.; Larroche, C.; Moulti-Mati, F.; Michaud, P. Olive mill wastes: Biochemical characterizations and valorization strategies. Process. Biochem. 2013, 48, 1532-1552. [CrossRef]

6. Rahmanian, N.; Jafari, S.M.; Galanakis, C.M. Recovery and removal of phenolic compounds from olive mill wastewater. J. Am. Oil Chem. Soc. 2014, 91, 1-18. [CrossRef]

7. Ammar, S.; Contreras, M.D.M.; Gargouri, B.; Segura-Carretero, A.; Bouaziz, M. RP-HPLC-DAD-ESI-QTOF-MS based metabolic profiling of the potential Olea europaea by-product "wood" and its comparison with leaf counterpart. Phytochem. Anal. 2017, 28, 217-229. [CrossRef]

8. Savarese, M.; De Marco, E.; Sacchi, R. Characterization of phenolic extracts from olives (Olea europaea cv. Pisciottana) by electrospray ionization mass spectrometry. Food Chem. 2007, 105, 761-770. [CrossRef]

9. Bouaziz, M.; Sayadi, S. Isolation and evaluation of antioxidants from leaves of a Tunisian cultivar olive tree. Eur. J. Lipid Sci. Technol. 2005, 107, 497-504. [CrossRef]

10. Bouaziz, M.; Grayer, R.J.; Simmonds, M.S.J.; Damak, M.; Sayadi, S. Identification and antioxidant potential of flavonoids and low molecular weight phenols in olive cultivar Chemlali growing in Tunisia. J. Agric. Food Chem. 2005, 53, 236-241. [CrossRef]

11. Pérez-Bonilla, M.; Salido, S.; van Beek, T.A.; Linares-Palomino, P.J.; Altarejos, J.; Nogueras, M.; Sánchez, A. Isolation and identification of radical scavengers in olive tree (Olea europaea) wood. J. Chromatogr. A 2006, 1112, 311-318. [CrossRef] [PubMed]

12. Vichi, S.; Cortés-Francisco, N.; Caixach, J. Insight into virgin olive oil secoiridoids characterization by high-resolution mass spectrometry and accurate mass measurements. J. Chromatogr. A 2013, 1301, 48-59. [CrossRef] 
13. Şahin, S.; Bilgin, M. Olive tree (Olea europaea L.) leaf as a waste by-product of table olive and olive oil industry: A review. J. Sci. Food Agric. 2018, 98, 1271-1279. [CrossRef] [PubMed]

14. Flamminii, F.; Di Mattia, C.D.; Nardella, M.; Chiarini, M.; Valbonetti, L.; Neri, L.; Difonzo, G.; Pittia, P. Structuring alginate beads with different biopolymers for the development of functional ingredients loaded with olive leaves phenolic extract. Food Hydrocoll. 2020, 108, 105849. [CrossRef]

15. Alcaide, E.M.; Nefzaoui, A. Recycling of Olive Oil By-Products: Possibilities of Utilization in Animal Nutrition. Int. Biodeterior. Biodegrad. 1996, 38, 227-235. [CrossRef]

16. Hidalgo-Carrillo, J.; Martín-Gómez, J.; Herrera-Beurnio, M.C.; Estévez, R.C.; Urbano, F.J.; Marinas, A. Olive leaves as biotemplates for enhanced solar-light harvesting by a titania-based solid. Nanomaterials 2020, 10, 1057. [CrossRef] [PubMed]

17. Cedola, A.; Palermo, C.; Centonze, D.; Del Nobile, M.A.; Conte, A. Characterization and bio-accessibility evaluation of olive leaf extract-enriched "Taralli". Foods 2020, 9, 1268. [CrossRef]

18. Inglezakis, V.J.; Moreno, J.L.; Doula, M.K. Olive oil waste management EU legislation: Current situation and policy recommendations. Int. J. Chem. Environ. Eng. Syst. 2012, 3, 65-77.

19. Guinda, Á. Use of solid residue from the olive industry. Grasas y Aceites 2006, 57, 107-115. [CrossRef]

20. Kamran, M. Olive (Olea Europaea L.) Leaf Biophenols as Nutraceuticals; Charles Sturt University: Bathurst, Australia, 2016.

21. Ben Salem, M.; Affes, H.; Ksouda, K.; Sahnoun, Z.; Zeghal, K.M.; Hammami, S. Pharmacological Activities of Olea europaea Leaves. J. Food Process. Preserv. 2015, 39, 3128-3136. [CrossRef]

22. Ranalli, A.; Contento, S.; Lucera, L.; Di Febo, M.; Marchegiani, D.; Di Fonzo, V. Factors affecting the contents of iridoid oleuropein in olive leaves (Olea europaea L.). J. Agric. Food Chem. 2006, 54, 434-440. [CrossRef] [PubMed]

23. Difonzo, G.; Russo, A.; Trani, A.; Paradiso, V.M.; Ranieri, M.; Pasqualone, A.; Summo, C.; Tamma, G.; Silletti, R.; Caponio, F. Green extracts from Coratina olive cultivar leaves: Antioxidant characterization and biological activity. J. Funct. Foods 2017, 31, 63-70. [CrossRef]

24. Liu, Y.; McKeever, L.C.; Suo, Y.; Jin, T.Z.; Malik, N.S.A. Antimicrobial Activities of Olive Leaf Extract and Its Potential Use in Food Industry. ACS Symp. Ser. 2018, 1287, 119-132. [CrossRef]

25. Noori, N.; Rajabian, M.; Nasrabadi, H.G.; Soofiani, M.R.A. Effect of Olea europaea Leaf Extract as A Prebiotic on Survival of Lactobacillus casei in UF Cheese During Cold Storage. J. Veterenary Res. 2020, 75, FA38-FA46. [CrossRef]

26. Guglielmotti, M.; Passaghe, P.; Buiatti, S. Use of olive (Olea europaea L.) leaves as beer ingredient, and their influence on beer chemical composition and antioxidant activity. J. Food Sci. 2020, 85, 2278-2285. [CrossRef] [PubMed]

27. Gambacorta, G.; Faccia, M.; Previtali, M.A.; Pati, S.; Notte, E.L.; Baiano, A. Effects of olive maturation and stoning on quality indices and antioxidant content of extra virgin oils (cv. coratina) during storage. J. Food Sci. 2010, 75, C229-C235. [CrossRef] [PubMed]

28. Cinquanta, L.; Esti, M.; La Notte, E. Evolution of phenolic compounds in virgin olive oil during storage. J. Am. Oil Chem. Soc. 1997, 74, 1259-1264. [CrossRef]

29. Malheiro, R.; Casal, S.; Teixeira, H.; Bento, A.; Pereira, J.A. Effect of Olive Leaves Addition during the Extraction Process of Overmature Fruits on Olive Oil Quality. Food Bioprocess. Technol. 2013, 6, 509-521. [CrossRef]

30. Kiritsakis, K.; Kontominas, M.G.; Kontogiorgis, C.; Hadjipavlou-Litina, D.; Moustakas, A.; Kiritsakis, A. Composition and antioxidant activity of olive leaf extracts from Greek olive cultivars. J. Am. Oil Chem. Soc. 2010, 87, 369-376. [CrossRef]

31. Paiva-Martins, F.; Correia, R.; Félix, S.; Ferreira, P.; Gordon, M.H. Effects of enrichment of refined olive oil with phenolic compounds from olive leaves. J. Agric. Food Chem. 2007, 55, 4139-4143. [CrossRef]

32. Calvano, C.D.; Ventura, G.; Cataldi, T.R.I.; Palmisano, F. Improvement of chlorophyll identification in foodstuffs by MALDI ToF/ToF mass spectrometry using 1,5-diaminonaphthalene electron transfer secondary reaction matrix. Anal. Bioanal. Chem. 2015, 407, 6369-6379. [CrossRef] [PubMed]

33. Calvano, C.D.; Ventura, G.; Trotta, M.; Bianco, G.; Cataldi, T.R.I.; Palmisano, F. Electron-Transfer Secondary Reaction Matrices for MALDI MS Analysis of Bacteriochlorophyll a in Rhodobacter sphaeroides and Its Zinc and Copper Analogue Pigments. J. Am. Soc. Mass Spectrom. 2017, 28, 125-135. [CrossRef]

34. Tarchoune, I.; Sgherri, C.; Eddouzi, J.; Zinnai, A.; Quartacci, M.F.; Zarrouk, M. Olive leaf addition increases olive oil nutraceutical properties. Molecules 2019, 24, 545. [CrossRef] [PubMed]

35. Ross, I.A. Olea europaea. In Medicinal Plants of the World; Humana Press: Totowa, NJ, USA, 2007; Volume 3, pp. $373-400$.

36. Ribeiro, R.D.A.; De Melo, M.R.; De Barros, F.; Gomes, C.; Trolin, G. Acute antihypertensive effect in conscious rats produced by some medicinal plants used in the state of São Paulo. J. Ethnopharmacol. 1986, 15, 261-269. [CrossRef]

37. Darias, V.; Bravo, L.; Barquin, E.; Herrera, D.M.; Fraile, C. Contribution to the ethnopharmacological study of the Canary Islands. J. Ethnopharmacol. 1986, 15, 169-193. [CrossRef]

38. Reynolds, J.E.F. Martindale: The Extra Pharmacopoeia, 31st ed.; Royal Pharmaceutical Society of Great Britain, Ed.; Royal Pharmaceutical Society: London, UK, 1996.

39. De Feo, V.; Senatore, F. Medicinal plants and phytotherapy in the Amalfitan Coast, Salerno Province, Campania, Southern Italy. J. Ethnopharmacol. 1993, 39, 39-51. [CrossRef]

40. Pieroni, A.; Heimler, D.; Pieters, L.; Van Poel, B.; Vlietinck, A.J. In vitro anti-complementary activity of flavonoids from olive (Olea europaea L.) leaves. Pharmazie 1996, 51, 765-768. 
41. Bellakhdar, J.; Claisse, R.; Fleurentin, J.; Younos, C. Repertory of standard herbal drugs in the Moroccan pharmacopoea. J. Ethnopharmacol. 1991, 35, 123-143. [CrossRef]

42. Simpson, G.E. Folk Medicine in Trinidad. J. Am. Folk. 1962, 75, 326. [CrossRef]

43. Vardanian, S.A. Phytotherapy of bronchial asthma in medieval Armenian medicine. Ter. Arkhiv 1978, 50, $133-136$.

44. Dilucia, F.; Lacivita, V.; Conte, A.; Del Nobile, M.A. Sustainable Use of Fruit and Vegetable By-Products to Enhance Food Packaging Performance. Foods 2020, 9, 857. [CrossRef]

45. Bastante, C.C.; Cardoso, L.C.; Fernández-Ponce, M.T.; Serrano, C.M.; de la Ossa, E.J.M. Supercritical impregnation of olive leaf extract to obtain bioactive films effective in cherry tomato preservation. Food Packag. Shelf Life 2019, 21, 100338. [CrossRef]

46. European Environment Agency. Diverting waste from landfill: Effectiveness of waste management policies in the European Union. EEA Rep. 2009, 1-68.

47. Istituto Superiore per la protezione e la Ricerca Ambientale (ISPRA). Rapporto Rifiuti Speciali Edizione 2017. Available online: https:/ / www.isprambiente.gov.it/it/pubblicazioni/rapporti/rapporto-rifiuti-speciali-edizione-2017 (accessed on 18 April 2021).

48. Demichelis, F.; Piovano, F.; Fiore, S. Biowaste Management in Italy: Challenges and Perspectives. Sustainability 2019, 11, 4213. [CrossRef]

49. Malapert, A.; Reboul, E.; Loonis, M.; Dangles, O.; Tomao, V. Direct and Rapid Profiling of Biophenols in Olive Pomace by UHPLC-DAD-MS. Food Anal. Methods 2018, 11, 1001-1010. [CrossRef]

50. Nunes, M.A.; Costa, A.S.G.; Bessada, S.; Santos, J.; Puga, H.; Alves, R.C.; Freitas, V.; Oliveira, M.B.P.P. Olive pomace as a valuable source of bioactive compounds: A study regarding its lipid- and water-soluble components. Sci. Total Environ. 2018, 644, 229-236. [CrossRef] [PubMed]

51. Lama-Muñoz, A.; Rodríguez-Gutiérrez, G.; Rubio-Senent, F.; Fernández-Bolaños, J. Production, characterization and isolation of neutral and pectic oligosaccharides with low molecular weights from olive by-products thermally treated. Food Hydrocoll. 2012, 28, 92-104. [CrossRef]

52. Tortosa, G.; González-Gordo, S.; Ruiz, C.; Bedmar, E.J.; Palma, J.M. “Alperujo” compost improves the ascorbate (Vitamin C) content in pepper (Capsicum annuum L.) fruits and influences their oxidative metabolism. Agronomy 2018, 8, 82. [CrossRef]

53. Romero-García, J.M.; Niño, L.; Martínez-Patiño, C.; Álvarez, C.; Castro, E.; Negro, M.J. Biorefinery based on olive biomass. State of the art and future trends. Bioresour. Technol. 2014, 159, 421-432. [CrossRef]

54. Bonet-Ragel, K.; Canet, A.; Benaiges, M.D.; Valero, F. Synthesis of biodiesel from high FFA alperujo oil catalysed by immobilised lipase. Fuel 2015, 161, 12-17. [CrossRef]

55. Ghilardi, C.; Negrete, P.S.; Carelli, A.A.; Borroni, V. Evaluation of olive mill waste as substrate for carotenoid production by Rhodotorula mucilaginosa. Bioresour. Bioprocess. 2020, 7, 1-11. [CrossRef]

56. de la Casa, J.A.; Lorite, M.; Jiménez, J.; Castro, E. Valorisation of wastewater from two-phase olive oil extraction in fired clay brick production. J. Hazard. Mater. 2009, 169, 271-278. [CrossRef]

57. Uceda-Rodríguez, M.; López-García, A.B.; Moreno-Maroto, J.M.; Cobo-Ceacero, C.J.; Cotes-Palomino, M.T.; García, C.M Evaluation of the environmental benefits associated with the addition of olive pomace in the manufacture of lightweight aggregates. Materials 2020, 13, 2351. [CrossRef] [PubMed]

58. Medina, E.; Romero, C.; Brenes, M. Residual Olive Paste as a Source of Phenolic Compounds and Triterpenic Acids. Eur. J. Lipid Sci. Technol. 2018, 120, 1700368. [CrossRef]

59. Zambonin, C.G.; Calvano, C.D.; D'Accolti, L.; Palmisano, F. Laser desorption/ionization time-of-flight mass spectrometry of squalene in oil samples. Rapid Commun. Mass Spectrom. 2006, 20, 325-327. [CrossRef] [PubMed]

60. Rigane, G.; Salem, R. Ben Microwave-assisted extraction of hydroxytyrosol from alperujo and its impact on the stability of mayonnaise. J. Indian Chem. Soc. 2020, 97, 67-74.

61. Spizzirri, U.G.; Carullo, G.; Aiello, F.; Paolino, D.; Restuccia, D. Valorisation of olive oil pomace extracts for a functional pear beverage formulation. Int. J. Food Sci. Technol. 2020, 14591. [CrossRef]

62. Di Nunzio, M.; Picone, G.; Pasini, F.; Chiarello, E.; Caboni, M.F.; Capozzi, F.; Gianotti, A.; Bordoni, A. Olive oil by-product as functional ingredient in bakery products. Influence of processing and evaluation of biological effects. Food Res. Int. 2020, 131, 108940. [CrossRef]

63. Nasopoulou, C.; Smith, T.; Detopoulou, M.; Tsikrika, C.; Papaharisis, L.; Barkas, D.; Zabetakis, I. Structural elucidation of olive pomace fed sea bass (Dicentrarchus labrax) polar lipids with cardioprotective activities. Food Chem. 2014, 145, 1097-1105. [CrossRef]

64. Gisbert, E.; Andree, K.B.; Quintela, J.C.; Calduch-Giner, J.A.; Ipharraguerre, I.R.; Pérez-Sánchez, J. Olive oil bioactive compounds increase body weight, and improve gut health and integrity in gilthead sea bream (Sparus aurata). Br. J. Nutr. 2017, 117, 351-363. [CrossRef]

65. Nunes, M.A.; Pimentel, F.B.; Costa, A.S.G.; Alves, R.C.; Oliveira, M.B.P.P. Olive by-products for functional and food applications: Challenging opportunities to face environmental constraints. Innov. Food Sci. Emerg. Technol. 2016, 35, 139-148. [CrossRef]

66. La Scalia, G.; Micale, R.; Cannizzaro, L.; Marra, F.P. A sustainable phenolic compound extraction system from olive oil mill wastewater. J. Clean. Prod. 2017, 142, 3782-3788. [CrossRef]

67. Zbakh, H.; El Abbassi, A. Potential use of olive mill wastewater in the preparation of functional beverages: A review. J. Funct. Foods 2012, 4, 53-65. [CrossRef]

68. Paraskeva, P.; Diamadopoulos, E. Technologies for olive mill wastewater (OMW) treatment: A review. J. Chem. Technol. Biotechnol. 2006, 81, 1475-1485. [CrossRef] 
69. Morillo, J.A.; Antizar-Ladislao, B.; Monteoliva-Sánchez, M.; Ramos-Cormenzana, A.; Russell, N.J. Bioremediation and biovalorisation of olive-mill wastes. Appl. Microbiol. Biotechnol. 2009, 82, 25-39. [CrossRef]

70. Aviani, I.; Raviv, M.; Hadar, Y.; Saadi, I.; Dag, A.; Ben-Gal, A.; Yermiyahu, U.; Zipori, I.; Laor, Y. Effects of harvest date, irrigation level, cultivar type and fruit water content on olive mill wastewater generated by a laboratory scale "Abencor" milling system. Bioresour. Technol. 2012, 107, 87-96. [CrossRef] [PubMed]

71. Khdair, A.; Abu-Rumman, G. Sustainable Environmental Management and Valorization Options for Olive Mill Byproducts in the Middle East and North Africa (MENA) Region. Processes 2020, 8, 671. [CrossRef]

72. Justino, C.I.L.; Pereira, R.; Freitas, A.C.; Rocha-Santos, T.A.P.; Panteleitchouk, T.S.L.; Duarte, A.C. Olive oil mill wastewaters before and after treatment: A critical review from the ecotoxicological point of view. Ecotoxicology 2012, 21, 615-629. [CrossRef]

73. Ouzounidou, G.; Zervakis, G.; Gaitis, F. Raw and microbiologically detoxified olive mill waste and their impact on plant growth Terr. Aquat. Environ. Toxicol. 2010, 4, 21-38.

74. Torrecilla, J.S. Phenolic Compounds in Olive Oil Mill Wastewater. In Olives and Olive Oil in Health and Disease Prevention; Elsevier: Amsterdam, The Netherlands, 2010; pp. 357-365. ISBN 9780123744203.

75. Bonvino, N.P.; Liang, J.; McCord, E.D.; Zafiris, E.; Benetti, N.; Ray, N.B.; Hung, A.; Boskou, D.; Karagiannis, T.C. OliveNet ${ }^{\text {TM}}$ : A comprehensive library of compounds from Olea europaea. Database 2018, 2018, 1-9. [CrossRef]

76. Ventura, G.; Calvano, C.D.; Abbattista, R.; Bianco, M.; De Ceglie, C.; Losito, I.; Palmisano, F.; Cataldi, T.R.I. Characterization of bioactive and nutraceutical compounds occurring in olive oil processing wastes. Rapid Commun. Mass Spectrom. 2019, 33, 1670-1681. [CrossRef]

77. Obied, H.K.; Allen, M.S.; Bedgood, D.R.; Prenzler, P.D.; Robards, K. Investigation of Australian Olive Mill Waste for Recovery of Biophenols. J. Agric. Food Chem. 2005, 53, 9911-9920. [CrossRef] [PubMed]

78. Barbera, A.C.; Maucieri, C.; Cavallaro, V.; Ioppolo, A.; Spagna, G. Effects of spreading olive mill wastewater on soil properties and crops, a review. Agric. Water Manag. 2013, 119, 43-53. [CrossRef]

79. Venturi, F.; Sanmartin, C.; Taglieri, I.; Nari, A.; Andrich, G.; Terzuoli, E.; Donnini, S.; Nicolella, C.; Zinnai, A. Development of phenol-enriched olive oil with phenolic compounds extracted from wastewater produced by physical refining. Nutrients 2017, 9, 916. [CrossRef]

80. Servili, M.; Esposto, S.; Veneziani, G.; Urbani, S.; Taticchi, A.; Di Maio, I.; Selvaggini, R.; Sordini, B.; Montedoro, G.F. Improvement of bioactive phenol content in virgin olive oil with an olive-vegetation water concentrate produced by membrane treatment. Food Chem. 2011, 124, 1308-1315. [CrossRef]

81. Caporaso, N.; Formisano, D.; Genovese, A. Use of phenolic compounds from olive mill wastewater as valuable ingredients for functional foods. Crit. Rev. Food Sci. Nutr. 2018, 58, 2829-2841. [CrossRef] [PubMed]

82. Panizzi, L.; Scarpati, M.L.; Oriente, G. The constitution of oleuropein, a bitter glucoside of the olive with hypotensive action. II. Gazz. Chim. Ital. 1960, 90, 1449-1485.

83. Bourquelot, E.; Vintilesco, J. Sur l’oleuropéine, nouveau principe de nature glucosidique retiré de l'Olivier. Acad. Sci. Paris 1908, 147, 533-536.

84. Capretti, G.; Bonaconza, E. Azione dell'infuso e del decotto di foglie di ulivo (Olea europea) su alcune costanti fisiche del sangue (viscosità e tensione superficiale) e su alcune componenti del ricambio (acido urico, cloruri, Na, K, colesterina). G. Clin. Med. $1949,30,630-642$.

85. Inouye, H.; Ueda, S.; Nakammura, Y. Studies on Monoterpene Glucosides. XII. Biosynthesis of Gentianaceous Secoiridoid Glucosides. Chem. Pharm. Bull. 1970, 18, 2043-2049. [CrossRef]

86. Inouye, H.; Ueda, S.; Aoki, Y.; Takeda, Y. Studies on Monoterpene Glucosides and Related Natural Products. XVII. The Intermediacy of 7-Desoxyloganic Acid and Loganin in the Biosynthesis of Several Iridoid Glucosides. Chem. Pharm. Bull. 1972, 20, 1287-1296. [CrossRef]

87. Inouye, H.; Ueda, S.; Inoue, K.; Takeda, Y. Studies on Monoterpene Glucosides and Related Natural Products. XXIII. Biosynthesis of the Secoiridoid Glucosides, Gentiopicroside, Morroniside, Oleuropein, and Jasminin. Chem. Pharm. Bull. 1974, 22, 676-686. [CrossRef]

88. Ragazzi, E.; Veronese, G.; Guiotto, A. Demethyloleoeuropeine, a new glucoside from ripe olives. Ann. Chim. Rome 1973.

89. Gariboldi, P.; Jommi, G.; Verotta, L. Secoiridoids from Olea europaea. Phytochemistry 1986, 25, 865-869. [CrossRef]

90. MacKellar, F.A.; Kelly, R.C.; Van Tamelen, E.E.; Dorschel, C. Structure and stereochemistry of elenolic acid. J. Am. Chem. Soc. 1973, 95, 7155-7156. [CrossRef]

91. Kuwajima, H.; Uemura, T.; Takaishi, K.; Inoue, K.; Inouyet, H. A secoiridoid glucoside from Olea europaea. Phytochemistry 1988, 27, 1757-1759. [CrossRef]

92. Capasso, R.; Evidente, A.; Visca, C.; Gianfreda, L.; Maremonti, M.; Greco, G. Production of glucose and bioactive aglycone by chemical and enzymatic hydrolysis of purified oleuropein from Olea Europea. Appl. Biochem. Biotechnol. 1997, 61, 365-377. [CrossRef]

93. De Nino, A.; Lombardo, N.; Perri, E.; Procopio, A.; Raffaelli, A.; Sindona, G. Direct identification of phenolic glucosides from olive leaf extracts by atmospheric pressure ionization tandem mass spectrometry. J. Mass Spectrom. 1997, 32, 533-541. [CrossRef]

94. Silva, S.; Gomes, L.; Leitão, F.; Coelho, A.V.; Boas, L.V. Phenolic Compounds and Antioxidant Activity of Olea europaea L. Fruits and Leaves. Food Sci. Technol. Int. 2006, 12, 385-395. [CrossRef]

95. Fabbri, A.; Galaverna, G.; Ganino, T. Polyphenol composition of olive leaves with regard to cultivar, time of collection and shoot type. Acta Hortic. 2008, 459-464. [CrossRef] 
96. Luján, R.J.; Capote, F.P.; Marinas, A.; de Castro, M.D.L. Liquid chromatography/triple quadrupole tandem mass spectrometry with multiple reaction monitoring for optimal selection of transitions to evaluate nutraceuticals from olive-tree materials. Rapid Commun. Mass Spectrom. 2008, 22, 855-864. [CrossRef]

97. Goulas, V.; Exarchou, V.; Troganis, A.N.; Psomiadou, E.; Fotsis, T.; Briasoulis, E.; Gerothanassis, I.P. Phytochemicals in olive-leaf extracts and their antiproliferative activity against cancer and endothelial cells. Mol. Nutr. Food Res. 2009, 53, 600-608. [CrossRef]

98. Laguerre, M.; Giraldo, L.J.L.; Piombo, G.; Figueroa-Espinoza, M.C.; Pina, M.; Benaissa, M.; Combe, A.; Castera, A.R.; Lecomte, J.; Villeneuve, P. Characterization of olive-leaf phenolics by esi-ms and evaluation of their antioxidant capacities by the cat assay. $J$. Am. Oil Chem. Soc. 2009, 86, 1215-1225. [CrossRef]

99. Fu, S.; Arráez-Roman, D.; Segura-Carretero, A.; Menéndez, J.A.; Menéndez-Gutiérrez, M.P.; Micol, V.; Fernández-Gutiérrez, A. Qualitative screening of phenolic compounds in olive leaf extracts by hyphenated liquid chromatography and preliminary evaluation of cytotoxic activity against human breast cancer cells. Anal. Bioanal. Chem. 2010, 397, 643-654. [CrossRef] [PubMed]

100. Taamalli, A.; Arráez-Román, D.; Ibañez, E.; Zarrouk, M.; Segura-Carretero, A.; Fernández-Gutiérrez, A. Optimization of microwave-assisted extraction for the characterization of olive leaf phenolic compounds by using HPLC-ESI-TOF-MS/IT-MS2. J. Agric. Food Chem. 2012, 60, 791-798. [CrossRef] [PubMed]

101. Quirantes-Piné, R.; Lozano-Sánchez, J.; Herrero, M.; Ibáñez, E.; Segura-Carretero, A.; Fernández-Gutiérrez, A. HPLC-ESI-QTOFMS as a Powerful Analytical Tool for Characterising Phenolic Compounds in Olive-leaf Extracts. Phytochem. Anal. 2013, 24, 213-223. [CrossRef]

102. Talhaoui, N.; Gómez-Caravaca, A.M.; León, L.; De la Rosa, R.; Segura-Carretero, A.; Fernández-Gutiérrez, A. Determination of phenolic compounds of "Sikitita" olive leaves by HPLC-DAD-TOF-MS. Comparison with its parents "Arbequina" and "Picual" olive leaves. LWT-Food Sci. Technol. 2014, 58, 28-34. [CrossRef]

103. Tóth, G.; Alberti, Á.; Sólyomváry, A.; Barabás, C.; Boldizsár, I.; Noszál, B. Phenolic profiling of various olive bark-types and leaves: HPLC-ESI/MS study. Ind. Crop. Prod. 2015, 67, 432-438. [CrossRef]

104. Rodr, C.; Quirantes-pin, R.; Men, J. Composition and Analysis of Functional Components of Olive Leaves. Olives Olive Oil Funct. Foods 2017, 383-399. [CrossRef]

105. Cittan, M.; Çelik, A. Development and validation of an analytical methodology based on liquid chromatography-electrospray tandem mass spectrometry for the simultaneous determination of phenolic compounds in olive leaf extract. J. Chromatogr. Sci. 2018, 56, 336-343. [CrossRef] [PubMed]

106. Olmo-García, L.; Kessler, N.; Neuweger, H.; Wendt, K.; Olmo-Peinado, J.; Fernández-Gutiérrez, A.; Baessmann, C.; CarrascoPancorbo, A. Unravelling the Distribution of Secondary Metabolites in Olea europaea L.: Exhaustive Characterization of Eight Olive-Tree Derived Matrices by Complementary Platforms (LC-ESI/APCI-MS and GC-APCI-MS). Molecules 2018, 23, 2419. [CrossRef]

107. Kanakis, P.; Termentzi, A.; Michel, T.; Gikas, E.; Halabalaki, M.; Skaltsounis, A.L. From olive drupes to olive OilAn HPLCorbitrap-based qualitative and quantitative exploration of olive key metabolites. Planta Med. 2013, 79, 1576-1587. [CrossRef]

108. Michel, T.; Khlif, I.; Kanakis, P.; Termentzi, A.; Allouche, N.; Halabalaki, M.; Skaltsounis, A.L. UHPLC-DAD-FLD and UHPLCHRMS/MS based metabolic profiling and characterization of different Olea europaea organs of Koroneiki and Chetoui varieties. Phytochem. Lett. 2015, 11, 424-439. [CrossRef]

109. Kritikou, E.; Kalogiouri, N.P.; Kolyvira, L.; Thomaidis, N.S. Target and Suspect HRMS Metabolomics for the Determination of Functional Ingredients in 13 Varieties of Olive Leaves and Drupes from Greece. Molecules 2020, 25, 4889. [CrossRef] [PubMed]

110. Abbattista, R.; Losito, I.; De Ceglie, C.; Castellaneta, A.; Calvano, C.D.; Palmisano, F.; Cataldi, T.R. A comprehensive study of oleuropein aglycone isomers in olive oil by enzymatic/chemical processes and liquid chromatography-Fourier transform mass spectrometry integrated by H/D exchange. Talanta 2019, 205, 120107. [CrossRef]

111. Abbattista, R.; Losito, I.; De Ceglie, C.; Basile, G.; Calvano, C.D.; Palmisano, F.; Cataldi, T.R. Structural characterization of the ligstroside aglycone isoforms in virgin olive oils by liquid chromatography-high-resolution Fourier-transform mass spectrometry and H/Dexchange. J. Mass Spectrom. 2019, 54, 843-855. [CrossRef]

112. Ryan, D.; Antolovich, M.; Prenzler, P.; Robards, K.; Lavee, S. Biotransformations of phenolic compounds in Olea europaea L. Sci. Hortic. 2002, 92, 147-176. [CrossRef]

113. Juven, B.; Henis, Y.; Jacoby, B. Studies on the Mechanism of the Antimicrobial Action of Oleuropein*. J. Appl. Bacteriol. 1972, 35, 559-567. [CrossRef]

114. Lee-Huang, S.; Zhang, L.; Huang, P.L.; Chang, Y.-T.; Huang, P.L. Anti-HIV activity of olive leaf extract (OLE) and modulation of host cell gene expression by HIV-1 infection and OLE treatment. Biochem. Biophys. Res. Commun. 2003, 307, 1029-1037. [CrossRef]

115. Omar, S.H. Cardioprotective and neuroprotective roles of oleuropein in olive. Saudi Pharm. J. 2010, 18, 111-121. [CrossRef]

116. Romero, M.; Toral, M.; Gómez-Guzmán, M.; Jiménez, R.; Galindo, P.; Sánchez, M.; Olivares, M.; Gálvez, J.; Duarte, J. Antihypertensive effects of oleuropein-enriched olive leaf extract in spontaneously hypertensive rats. Food Funct. 2016, 7, 584-593. [CrossRef]

117. Obied, H.K.; Prenzler, P.D.; Omar, S.H.; Ismael, R.; Servili, M.; Esposto, S.; Taticchi, A.; Selvaggini, R.; Urbani, S. Pharmacology of olive biophenols. In Advances in Molecular Toxicology; Elsevier B.V.: Amsterdam, The Netherlands, 2012; Volume 6, pp. $195-242$.

118. Cheurfa, M.; Abdallah, H.H.; Allem, R.; Noui, A.; Picot-Allain, C.M.N.; Mahomoodally, F. Hypocholesterolaemic and antioxidant properties of Olea europaea L. leaves from Chlef province, Algeria using in vitro, in vivo and in silico approaches. Food Chem. Toxicol. 2019, 123, 98-105. [CrossRef] 
119. Wainstein, J.; Ganz, T.; Boaz, M.; Bar Dayan, Y.; Dolev, E.; Kerem, Z.; Madar, Z. Olive leaf extract as a hypoglycemic agent in both human diabetic subjects and in rats. J. Med. Food 2012, 15, 605-610. [CrossRef]

120. Van der Stelt, I.; Van den Hil, E.F.H.; Swarts, H.J.M.; Vervoort, J.J.M.; Hoving, L.; Skaltsounis, L.; Lemonakis, N.; Andreadou, I.; van Schothorst, E.M.; Keijer, J. Nutraceutical oleuropein supplementation prevents high fat diet-induced adiposity in mice. J. Funct. Foods 2015, 14, 702-715. [CrossRef]

121. Ventura, G.; Abbattista, R.; Calvano, C.D.; De Ceglie, C.; Losito, I.; Palmisano, F.; Cataldi, T.R.I. Tandem mass spectrometry characterization of a conjugate between oleuropein and hydrated cis -diammineplatinum(II). Rapid Commun. Mass Spectrom. 2019, 33, 657-666. [CrossRef] [PubMed]

122. Le Tutour, B.; Guedon, D. Antioxidative activities of Olea europaea leaves and related phenolic compounds. Phytochemistry 1992, 31, 1173-1178. [CrossRef]

123. Lattanzio, V.; Veronica, M.T.; Lattanzio, A.C. Role of Phenolics in the Resistance Mechanisms of Plants Against Fungal Pathogens and Insects; Research Signpost: Kerala, India, 2015; Volume 661, ISBN 8130800349.

124. Kubo, I.; Matsumoto, A.; Takase, I. A multichemical defense mechanism of bitter olive Olea europaea (oleaceae)-Is oleuropein a phytoalexin precursor? J. Chem. Ecol. 1985, 11, 251-263. [CrossRef]

125. Spadafora, A.; Mazzuca, S.; Chiappetta, F.F.; Parise, A.; Perri, E.; Innocenti, A.M. Oleuropein-Specific- $\beta$-Glucosidase Activity Marks the Early Response of Olive Fruits (Olea europaea) to Mimed Insect Attack. Agric. Sci. China 2008, 7, 703-712. [CrossRef]

126. Ghanbari, R.; Anwar, F.; Alkharfy, K.M.; Gilani, A.H.; Saari, N. Valuable nutrients and functional bioactives in different parts of olive (Olea europaea L.)-A review. Int. J. Mol. Sci. 2012, 13, 1291-1340. [CrossRef]

127. Cardoso, S.M.; Guyot, S.; Marnet, N.; Lopes-da-Silva, J.A.; Renard, C.M.; Coimbra, M.A. Characterisation of phenolic extracts from olive pulp and olive pomace by electrospray mass spectrometry. J. Sci. Food Agric. 2005, 85, 21-32. [CrossRef]

128. Peralbo-Molina, Á.; Priego-Capote, F.; De Castro, M.D.L. Tentative identification of phenolic compounds in olive pomace extracts using liquid chromatography-tandem mass spectrometry with a quadrupole- quadrupole-time-of-flight mass detector. J. Agric. Food Chem. 2012, 60, 11542-11550. [CrossRef]

129. Rubio-Senent, F.; Martos, S.; Lama-Muñoz, A.; Fernández-Bolaños, J.G.; Rodríguez-Gutiérrez, G.; Fernández-Bolaños, J. Isolation and identification of minor secoiridoids and phenolic components from thermally treated olive oil by-products. Food Chem. 2015, 187, 166-173. [CrossRef]

130. Lama-Muñoz, A.; Rodríguez-Gutiérrez, G.; Rubio-Senent, F.; Palacios-Díaz, R.; Fernández-Bolaños, J. A study of the precursors of the natural antioxidant phenol 3,4-dihydroxyphenylglycol in olive oil waste. Food Chem. 2013, 140, 154-160. [CrossRef] [PubMed]

131. Pavez, I.C.; Lozano-Sánchez, J.; Borrás-Linares, I.; Nuñez, H.; Robert, P.; Segura-Carretero, A. Obtaining an extract rich in phenolic compounds from olive pomace by pressurized liquid extraction. Molecules 2019, 24, 3108. [CrossRef]

132. Suárez, M.; Romero, M.P.; Ramo, T.; Macià, A.; Motilva, M.J. Methods for preparing phenolic extracts from olive cake for potential application as food antioxidants. J. Agric. Food Chem. 2009, 57, 1463-1472. [CrossRef]

133. Klen, T.J.; Wondra, A.G.; Vrhovšek, U.; Vodopivec, B.M. Phenolic Profiling of Olives and Olive Oil Process-Derived Matrices Using UPLC-DAD-ESI-QTOF-HRMS Analysis. J. Agric. Food Chem. 2015, 63, 3859-3872. [CrossRef]

134. Obied, H.K.; Bedgood, D.R.; Prenzler, P.D.; Robards, K. Chemical screening of olive biophenol extracts by hyphenated liquid chromatography. Anal. Chim. Acta 2007, 603, 176-189. [CrossRef] [PubMed]

135. Cardinali, A.; Pati, S.; Minervini, F.; D'Antuono, I.; Linsalata, V.; Lattanzio, V. Verbascoside, isoverbascoside, and their derivatives recovered from olive mill wastewater as possible food antioxidants. J. Agric. Food Chem. 2012, 60, 1822-1829. [CrossRef] [PubMed]

136. D'Antuono, I.; Kontogianni, V.G.; Kotsiou, K.; Linsalata, V.; Logrieco, A.F.; Tasioula-Margari, M.; Cardinali, A. Polyphenolic characterization of olive mill wastewaters, coming from Italian and Greek olive cultivars, after membrane technology. Food Res. Int. 2014, 65, 301-310. [CrossRef]

137. Rigane, G.; Bouaziz, M.; Sayadi, S.; Ben Salem, R. Identification and characterization of a new iridoid compound from two-phase Chemlali olive pomace. Eur. Food Res. Technol. 2012, 234, 1049-1054. [CrossRef]

138. Mattonai, M.; Vinci, A.; Degano, I.; Ribechini, E.; Franceschi, M.; Modugno, F. Olive mill wastewaters: Quantitation of the phenolic content and profiling of elenolic acid derivatives using HPLC-DAD and HPLC/MS2 with an embedded polar group stationary phase. Nat. Prod. Res. 2019, 33, 3171-3175. [CrossRef] [PubMed]

139. Bazoti, F.N.; Gikas, E.; Skaltsounis, A.L.; Tsarbopoulos, A. Development of a liquid chromatography-electrospray ionization tandem mass spectrometry (LC-ESI MS/MS) method for the quantification of bioactive substances present in olive oil mill wastewaters. Anal. Chim. Acta 2006, 573-574, 258-266. [CrossRef]

140. Damak, N.; Allouche, N.; Hamdi, B.; Litaudon, M.; Damak, M. New secoiridoid from olive mill wastewater. Nat. Prod. Res. 2012, 26, 125-131. [CrossRef]

141. Ainsworth, E.A.; Gillespie, K.M. Estimation of total phenolic content and other oxidation substrates in plant tissues using Folin-Ciocalteu reagent. Nat. Protoc. 2007, 2, 875-877. [CrossRef]

142. Gullón, P.; Gullón, B.; Astray, G.; Carpena, M.; Fraga-Corral, M.; Prieto, M.A.; Simal-Gandara, J. Valorization of by-products from olive oil industry and added-value applications for innovative functional foods. Food Res. Int. 2020, $137,109683$. [CrossRef] [PubMed]

143. Romero, C.; Brenes, M.; García, P.; Garrido, A. Hydroxytyrosol 4- $\beta$-D-glucoside, an important phenolic compound in olive fruits and derived products. J. Agric. Food Chem. 2002, 50, 3835-3839. [CrossRef] 
144. Servili, M.; Baldioli, M.; Selvaggini, R.; Macchioni, A.; Montedoro, G.F. Phenolic compounds of olive fruit: One- and twodimensional nuclear magnetic resonance characterization of nuzhenide and its distribution in the constitutive parts of fruit. $J$. Agric. Food Chem. 1999, 47, 12-18. [CrossRef]

145. Esti, M.; Cinquanta, L.; La Notte, E. Phenolic Compounds in Different Olive Varieties. J. Agric. Food Chem. 1998, 46, 32-35. [CrossRef] [PubMed]

146. Cardoso, S.M.; Guyot, S.; Marnet, N.; Lopes-Da-Silva, J.A.; Silva, A.M.S.; Renard, C.M.G.C.; Coimbra, M.A. Identification of oleuropein oligomers in olive pulp and pomace. J. Sci. Food Agric. 2006, 86, 1495-1502. [CrossRef]

147. Cioffi, G.; Pesca, M.S.; De Caprariis, P.; Braca, A.; Severino, L.; De Tommasi, N. Phenolic compounds in olive oil and olive pomace from Cilento (Campania, Italy) and their antioxidant activity. Food Chem. 2010, 121, 105-111. [CrossRef]

148. Cicerale, S.; Conlan, X.A.; Barnett, N.W.; Keast, R.S.J. The concentration of oleocanthal in olive oil waste. Nat. Prod. Res. 2011, 25, 542-548. [CrossRef] [PubMed]

149. Lozano-Sánchez, J.; Giambanelli, E.; Quirantes-Piné, R.; Cerretani, L.; Bendini, A.; Segura-Carretero, A.; Fernández-Gutiérrez, A. Wastes generated during the storage of extra virgin olive oil as a natural source of phenolic compounds. J. Agric. Food Chem. 2011, 59, 11491-11500. [CrossRef]

150. Rubio-Senent, F.; Fernández-Bolaños, J.; García-Borrego, A.; Lama-Muñoz, A.; Rodríguez-Gutiérrez, G. Influence of pH on the antioxidant phenols solubilised from hydrothermally treated olive oil by-product (alperujo). Food Chem. 2017, 219, 339-345. [CrossRef] [PubMed]

151. Russo, M.; Bonaccorsi, I.L.; Cacciola, F.; Dugo, L.; De Gara, L.; Dugo, P.; Mondello, L. Distribution of bioactives in entire mill chain from the drupe to the oil and wastes. Nat. Prod. Res. 2020, 1-6. [CrossRef] [PubMed]

152. Rodríguez, G.; Lama, A.; Trujillo, M.; Espartero, J.L.; Fernández-Bolaños, J. Isolation of a powerful antioxidant from Olea europaea fruit-mill waste: 3,4-Dihydroxyphenylglycol. LWT-Food Sci. Technol. 2009, 42, 483-490. [CrossRef]

153. Del Coco, L.; De Pascali, S.A.; Iacovelli, V.; Cesari, G.; Schena, F.P.; Fanizzi, F.P. Following the olive oil production chain: 1D and 2D NMR study of olive paste, pomace, and oil. Eur. J. Lipid Sci. Technol. 2014, 116, 1513-1521. [CrossRef]

154. Hafidi, M.; Amir, S.; Revel, J.C. Structural characterization of olive mill waster-water after aerobic digestion using elemental analysis, FTIR and 13C NMR. Process. Biochem. 2005, 40, 2615-2622. [CrossRef]

155. Evci, E.; Yılmaz, Ö.; Bekfelavi, E.Y.; Kuş, N.S. Degradation of olive mill wastewater by different methods and antioxidant activity of olive mill wastewater extraction. SN Appl. Sci. 2019, 1, 1206. [CrossRef]

156. Losito, I.; Abbattista, R.; De Ceglie, C.; Castellaneta, A.; Calvano, C.D.; Cataldi, T.R.I. Bioactive Secoiridoids in Italian Extra-Virgin Olive Oils: Impact of Olive Plant Cultivars, Cultivation Regions and Processing. Molecules 2021, 26, 743. [CrossRef]

157. De Ceglie, C.; Abbattista, R.; Losito, I.; Castellaneta, A.; Calvano, C.D.; Bianco, G.; Palmisano, F.; Cataldi, T.R.I. Influence of Horizontal Centrifugation Processes on the Content of Phenolic Secoiridoids and Their Oxidized Derivatives in Commercial Olive Oils: An Insight by Liquid Chromatography-High-Resolution Mass Spectrometry and Chemometrics. J. Agric. Food Chem. 2020, 68, 3171-3183. [CrossRef]

158. Abbattista, R.; Losito, I.; Castellaneta, A.; De Ceglie, C.; Calvano, C.D.; Cataldi, T.R.I. Insight into the Storage-Related Oxidative/Hydrolytic Degradation of Olive Oil Secoiridoids by Liquid Chromatography and High-Resolution Fourier Transform Mass Spectrometry. J. Agric. Food Chem. 2020, 68, 12310-12325. [CrossRef]

159. Brenes, M.; Romero, C.; García, A.; Hidalgo, F.J.; Ruiz-Méndez, M.V. Phenolic compounds in olive oils intended for refining: Formation of 4-ethylphenol during olive paste storage. J. Agric. Food Chem. 2004, 52, 8177-8181. [CrossRef]

160. Tirado, D.F.; de la Fuente, E.; Calvo, L. A selective extraction of hydroxytyrosol rich olive oil from alperujo. J. Food Eng. 2019, 263, 409-416. [CrossRef]

161. Skaltsounis, A.L.; Argyropoulou, A.; Aligiannis, N.; Xynos, N. Recovery of High. Added Value Compounds from Olive Tree Products and Olive Processing Byproducts; AOCS Press: Urbana, IL, USA, 2015; ISBN 9781630670429.

162. Cardoso, S.M.; Falcão, S.I.; Peres, A.M.; Domingues, M.R.M. Oleuropein/ligstroside isomers and their derivatives in Portuguese olive mill wastewaters. Food Chem. 2011, 129, 291-296. [CrossRef]

163. Calvano, C.D.; Monopoli, A.; Ditaranto, N.; Palmisano, F. 1,8-Bis(dimethylamino)naphthalene/9-aminoacridine: A new binary matrix for lipid fingerprinting of intact bacteria by matrix assisted laser desorption ionization mass spectrometry. Anal. Chim. Acta 2013, 798, 56-63. [CrossRef] [PubMed] 